Technological University Dublin

DÜBLIN

ARROW@TU Dublin

Articles

School of Accounting and Finance

2021

\title{
The Impact of Quantitative Easing on Liquidity Creation
}

\author{
Supriya Kapoor \\ Technological University Dublin \\ Supriya Kapoor \\ Technological University Dublin \\ Oana Peia \\ Technological University Dublin
}

Follow this and additional works at: https://arrow.tudublin.ie/buschacart

Part of the Accounting Commons

\section{Recommended Citation}

Kapoor, S. \& Peia, O. (2021). The impact of quantitative easing on liquidity creation. Journal of Banking \& Finance, vol.122, 105998. doi:10.1016/j.jbankfin.2020.105998

This Article is brought to you for free and open access by the School of Accounting and Finance at ARROW@TU Dublin. It has been accepted for inclusion in Articles by an authorized administrator of ARROW@TU Dublin. For more information, please contact arrow.admin@tudublin.ie, aisling.coyne@tudublin.ie, gerard.connolly@tudublin.ie.

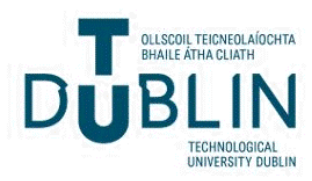




\title{
The impact of quantitative easing on liquidity creation
}

\author{
Supriya Kapoor ${ }^{\mathrm{a}}$, Oana Peia ${ }^{\mathrm{b}, *}$ \\ a School of Accounting and Finance, Technological University Dublin, Ireland \\ ${ }^{\mathrm{b}}$ School of Economics, University College Dublin, Ireland
}

\section{A R T I C L E I N F O}

\section{Article history:}

Received 28 April 2020

Accepted 31 October 2020

Available online 11 November 2020

\section{JEL classification:}

E52

E58

G21

\section{Keywords:}

Large-scale asset purchases

Quantitative easing

Liquidity creation

Bank lending

\begin{abstract}
A B S T R A C T
We study the effects of the US Federal Reserve's large-scale asset purchase programs during 20082014 on bank liquidity creation. Banks create liquidity when they transform the liquid reserves resulted from quantitative easing (QE) into illiquid assets. As the composition of banks' loan portfolio affects the amount of liquidity it creates, the impact of quantitative easing on liquidity creation is not a priori clear. Using a difference-in-difference identification strategy, we find that banks more affected by the policy increased lending relative to those less affected, mainly during the first and third round of QE. However, we only find a strong effect of the policy on liquidity creation during the third round of $\mathrm{QE}$. This points to a weaker impact on the real economy during the first two rounds, when more exposed banks transformed the reserves created through $\mathrm{QE}$ into less illiquid assets, such as real estate mortgages.
\end{abstract}

(c) 2020 The Authors. Published by Elsevier B.V. This is an open access article under the CC BY license (http://creativecommons.org/licenses/by/4.0/)

\section{Introduction}

Following the 2008-09 Global Financial Crisis, a growing number of central banks have included large-scale asset purchase programs (LSAPs) in their toolkit of unconventional monetary policies. The US Federal Reserve, in particular, implemented several rounds of quantitative easing $(\mathrm{QE})$ through which they purchased both agency mortgage-backed securities (MBS) and Treasury securities. ${ }^{1}$ The scale and unprecedented use of these unconventional policies has led to a large interest in understanding their effect on the banking sector and the real economy. Initial studies document an important effect of LSAPs on medium to long-term yields and asset prices through a signaling or portfolio-rebalancing channel

\footnotetext{
We would like to thank Karl Whelan, Ivan Pastine, Vlad Porumb, Vincent Hogan, Davide Romelli, Anuj Singh, Adnan Velic and Kate Hanniffy for useful comments and suggestions, as well as seminar participants at University College Dublin and Technological University Dublin, and participants to the 2019 Financial Engineering and Banking Society (FEBS) Conference and 5th HenU/INFER Workshop on Applied Macroeconomics.

* Corresponding author.

E-mail addresses: supriya.kapoor@tudublin.ie (S. Kapoor), oana.peia@ucd.ie, oana.peia@essec.edu (O. Peia).

1 The Federal Reserve implemented three rounds of QE following the Global Financial Crisis: the first (QE1) started in November 2008, the second (QE2) in November 2010 and third (QE3) in September 2012.
}

(Krishnamurthy and Vissing-Jorgensen, 2011; Gagnon et al., 2011; D’Amico et al., 2012). ${ }^{2}$

Quantitative easing can also lead to an increase in credit supply through a classical bank lending channel, as the new reserves and/or customer deposits created by QE represent a relatively cheap source of funding for banks, which can result in a shift in loan supply (Kashyap and Stein, 2000; Butt et al., 2014; Kandrac and Schlusche, 2017). ${ }^{3}$ Yet, evidence on the impact of QE on bank lending is more confounded. Rodnyansky and Darmouni (2017) and Luck and Zimmermann (2020) find that banks increased overall lending after the first and third rounds of quantitative easing, with the first corresponding mostly to an increase in mortgage origination, and the third round to an increase in both real estate, as well as commercial and industrial loans. Chakraborty et al. (2020), on the other hand, find that the increase in mortgage lending

\footnotetext{
2 Under these channels, the central bank affects the relative supply of different assets, thereby lowering their yields and increasing the prices of current asset holdings of banks. The strength of the effect generally depends on the type of assets the central bank is purchasing. For instance, Di Maggio et al. (2020) find that, while loan interest rates decreased on average as a result of the policy, the decrease was substantially larger for assets that were conforming with the Government Sponsored Enterprises (GSEs)-guaranteed mortgages that the Fed was purchasing.

3 Regardless of whether a bank or a bank customer is the ultimate seller of the securities purchased by the Federal Reserve through $\mathrm{QE}$, the reserves created by the policy will be held by banks. If the seller is a bank, securities are simply swapped for reserves on the bank's balance sheet. If the seller is a non-bank entity, bank deposits will also increase by the amount of securities sold to the Fed.
} 
crowded-out the origination of commercial loans, the latter actually decreasing as a result of the Fed's asset purchase programs.

In this paper, we study the implications of this heterogeneous impact of $\mathrm{QE}$ on lending for bank liquidity creation, one of the most important raison d'être of financial intermediaries. ${ }^{4}$ Banks create liquidity in the economy by financing relatively illiquid assets such as business loans with relatively liquid liabilities such as deposits (Bryant, 1980; Berger and Bouwman, 2009). This key role of financial intermediaries has been shown theoretically to improve the allocation of capital in the economy (Donaldson et al., 2018) and is robustly linked empirically to real output growth (Berger and Sedunov, 2017). As such, the ability of banks to provide liquidity was the main focus of policymakers at the peak of the 2008 Global Financial Crisis, when large and explicit government support was granted to banks to support liquidity creation (Acharya and Mora, 2015; Bai et al., 2018). However, the role of later unconventional policies such as LSAPs is less clear.

Through QE, the central bank purchases assets and credits the reserves account of banks, which can then use this liquidity injection to invest in relatively more illiquid assets, such as loans to businesses and individuals, thereby creating new liquidity in the economy. Crucial to our analysis are the types of loans given by banks, as their liquidity differs. For instance, classical measures of liquidity creation like Berger and Bouwman (2009) assume that loans that can be securitized and sold off the balance sheet, such as real estate mortgages, are less illiquid and, as such, lead to less liquidity creation in the economy. Hence, the amount of liquidity created in the banking sector depends on the composition of the asset side of banks' balance sheets as a result of this policy intervention.

We thus investigate the impact of the Fed's quantitative easing programs on bank liquidity creation using a sample of US bank-holding companies during 2006-2014. In doing so, we study the distributional effects of $\mathrm{QE}$ within the balance sheet of financial intermediaries using a difference-in-differences identification strategy that follows Rodnyansky and Darmouni (2017) and Luck and Zimmermann (2020). This strategy exploits the crosssectional variation in banks' exposure to the Fed's large-scale asset purchase programs. The underlying argument is that banks with a higher share of mortgage-backed securities in total assets benefited more from the program. ${ }^{5}$ We employ several definitions based on the share of MBS-to-total assets prior to QE to classify banks into treated and control groups and investigate the differential effect of the policy across banks.

We first study the impact of QE and bank lending. Similar to previous work, we find that banks with a higher MBS-to-total assets ratio had a disproportionally larger increase in lending. This differential effect is stronger during the first and third round of

\footnotetext{
${ }^{4}$ Modern theory of financial intermediation argues that banks exist to perform two central roles in the economy: create liquidity and transform risk (Diamond, 1984: Ramakrishnan and Thakor, 1984; Boyd and Prescott, 1986). While risk transformation and liquidity creation sometimes coincide - for example when riskless liquid liabilities are transformed into risky illiquid assets-, bank liquidity creation is often seen as a distinct function of banks (Gorton and Pennacchi, 1990; Gorton and Winton, 2003).

5 There are several reasons why banks that held more mortgage-backed securities benefited more from the large scale asset programs. First, during the three waves of $\mathrm{QE}$, the Fed focused on easing the deterioration in the MBS market by lowering yields and increasing the prices of banks' current asset holdings, thereby improving the balance sheets of banks that held higher shares of mortgage-backed securities. Second, banks with more MBS sold to the Fed saw a higher increase in reserves, which should have shifted their loan supply (Kandrac and Schlusche, 2017). Third, banks with higher MBS holdings might have a different business model and will particularly increase their real estate lending as their liquidity position improves. Finally, since the $\mathrm{QE}$ programs were largely unanticipated, especially the third round, banks that held more MBS had a prompt recovery in stocks and an improved capital position (see Washington Post, 2012).
}

$\mathrm{QE}$, when treated banks increased both real estate and commercial loans. However, while the increase in lending was present across the two rounds of $\mathrm{QE}$, we only find a robust effect on liquidity creation during the third round, when the Fed purchased a large amount of MBS securities. During this last round, banks with a higher MBS-to-total assets ratio created around 4\% more liquidity relative to their size as compared to the control group. This implies that, during the first two rounds, treated banks transformed the reserves created by $\mathrm{QE}$ into less illiquid assets such as real estate mortgages, pointing to a weaker impact of the policy on the real economy.

Our main measure of liquidity creation follows Berger and Bouwman (2009), however our results are robust to different definitions of liquidity creation proposed by Bai et al. (2018) or Deep and Schaefer (2004). Our findings also survive a battery of other robustness tests including various definitions of the treated and control groups, as well as controlling for bank-level characteristics. Furthermore, we include alongside bank fixed effects, yearquarter fixed effects to mitigate potential demand-side factors that can influence the composition of banks' loan portfolio and the amount of liquidity created on their balance sheets. The results are also robust to the inclusion of state-time fixed effects that allow us to control for aggregate demand conditions in a given state and quarter.

Our work provides a novel and robust channel through which unconventional monetary policy can affect the functioning of the banking sector and its impact on the real economy. This contributes to a growing empirical literature that studies the channels through which unconventional policies such as QE are transmitted through the economy. These channels include the signaling channel (Krishnamurthy and Vissing-Jorgensen, 2011; Bauer and Rudebusch, 2014), portfolio-rebalancing channel (Gagnon et al., 2011; D’Amico and King, 2013; Brunnermeier and Sannikov, 2016), reserves accumulation (Kandrac and Schlusche, 2017; Butt et al., 2014; Ryan and Whelan, 2019) or bank lending (Rodnyansky and Darmouni, 2017; Chakraborty et al., 2020).

Closest to our approach is the literature on the impact of $\mathrm{QE}$ on bank lending. For instance, Rodnyansky and Darmouni (2017) also exploit the cross-sectional variation of banks' exposure to mortgage-backed securities to show that banks with larger MBS holdings expanded both real estate and corporate lending more than their counterparts. Similarly, Luck and Zimmermann (2020) find that the first round of QE led to mostly an increase in mortgage origination, while in the third round both real estate and commercial lending increased. Chakraborty et al. (2020) also find that high-MBS banks disproportionally increased mortgage origination. However, they also show that these banks reduced commercial lending, suggesting a crowding out effect of $\mathrm{QE}$. The main difference between Chakraborty et al. (2020) and Rodnyansky and Darmouni (2017) rests in the way QE is defined. We use both definitions in this paper to study the role of QE in liquidity creation. Furthermore, Di Maggio et al. (2020) shows that the type of assets purchased through $\mathrm{QE}$ has an impact on the type of loans originated. For example, QE1, which involved significant purchases of GSE-guaranteed mortgages, increased GSE-guaranteed mortgage originations significantly more than the origination of non-GSE mortgages. Kandrac and Schlusche (2017) show that reserves created by the Fed as a result of the first two QE programs led to higher total loan growth and an increase in the share of riskier loans within banks' portfolios. Butt et al. (2014), on the other hand, find little effect of $\mathrm{QE}$ on lending in the UK, since they show that the increase in deposits created by the policy was short-lived. Similar evidence is provided in Ryan and Whelan (2019), who show that euro area banks mainly used the reserves created by the ECB's 
QE programs to purchase debt securities and less so to increase lending.

Our work complements these findings by focusing on a distinct channel through which $\mathrm{QE}$ might affect the real economy, i.e. liquidity creation. There are several reasons to focus on the impact of $\mathrm{QE}$ on liquidity creation. First, liquidity creation is a key role of financial intermediaries that has been shown to be a superior measure of bank output and an important channel that can explain the role of financial development in economic growth (Berger and Sedunov, 2017). Second, Donaldson et al. (2018) show theoretically how liquidity creation emerged historically as a key function of banks, through which bank lending increases aggregate investment in the economy by enabling positive net present value projects to be undertaken that would be unfeasible without bank liquidity creation. Moreover, the more illiquid the assets created by the bank, the more liquidity is created in the economy. This argument is in the spirit of empirical measures of liquidity creation such as Berger and Bouwman (2009) and Bai et al. (2018). These measures compute liquidity creation by assigning different weights to bank assets and liabilities depending on how easily they can be sold or redeemed, implying that banks contribute more to liquidity creation when they create more illiquid assets, such as commercial loans. Given the heterogeneous impact of $\mathrm{QE}$ on different types of loans suggested by previous research, the impact of the policy on liquidity creation is not obvious. Finally, measures of liquidity creation also include the liquidity created off-balance sheet through loan commitments or similar claims to liquid funds. As such, looking only at assets on the balance sheet might mask important effects of the policy, particularly if one type of lending crowds out another (as in Chakraborty et al., 2020).

Finally, our work is also related to a recent literature that looks at how banks' liquidity positions affect lending, in particular during periods of bank distress. For instance, Cornett et al. (2011) find that banks with more illiquid asset portfolios, i.e., those banks that held more loans and securitized assets, increased their holdings of liquid assets and decreased lending following the collapse of Lehman Brothers in 2008. Similarly, Dagher and Kazimov (2015) find that banks more exposed to wholesale funding shocks cut credit more for illiquid loans. Our work takes a new approach to understand how banks create liquidity by looking at the effect of policy interventions on this essential feature of financial intermediation.

The remainder of the paper is organized as follows. Section 2 describes our conceptual framework and the mechanism we investigate. Section 3 discusses the data and identification strategy. Section 4 presents our results, while Section 5 concludes.

\section{Transmission mechanism}

The Federal Reserve implemented three rounds of QE during 2008-2012 through which it purchased mortgage-backed and/or treasury securities by crediting the reserves accounts of banks who sold (or whose customers sold) securities to the Fed. ${ }^{6}$ If the final seller is a bank, securities are simply swapped for reserves on the bank's balance sheet. If the seller is a non-bank entity, bank deposits will also increase by the amount of securities sold to the

\footnotetext{
${ }^{6}$ In the first round (QE1), from 2008Q4 (November) to 2010Q2 (June), the Fed purchased $\$ 100$ billion GSE debt (bonds issued by government-sponsored enterprise- Ginnie Mae, Fannie Mae, Federal Loans \& Mortgage Corps, Freddie Mac) and $\$ 1,250$ billion Mortgage-backed securities (MBS) ( $\$ 500$ billion non-agency MBS and $\$ 750$ billion agency). The second round (QE2) was implemented from 2010Q4 (November) to 2011Q2 (June), where the Fed purchased $\$ 600$ billion Treasury bills. The third round (OE3) ran from 201203 (September) to 201403 (October) and included purchases of $\$ 40$ billion MBS and $\$ 45$ billion Treasury securities per month. At the end of the three rounds, the balance of the Fed contained $\$ 1.75$ trillion MBS and $\$ 1.68$ trillion Treasury bills.
}

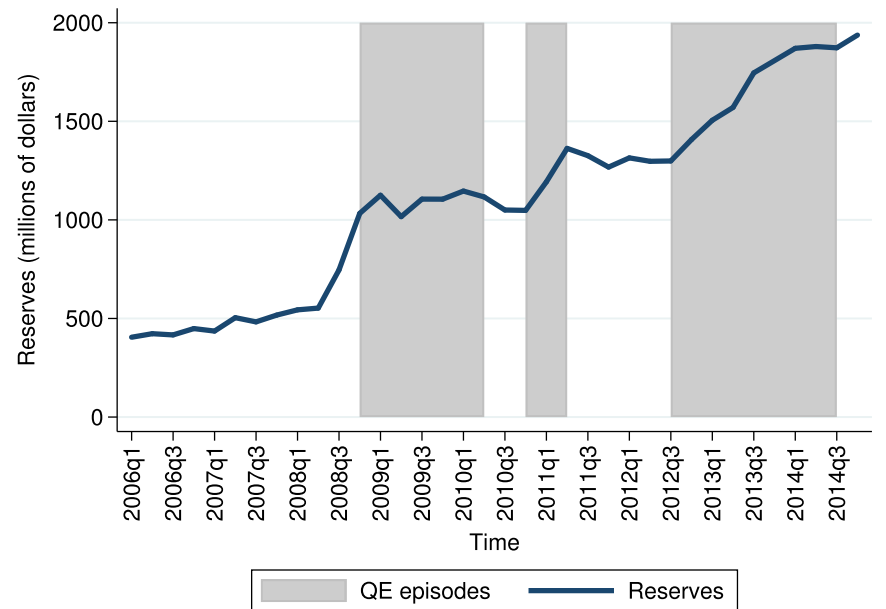

Fig. 1. Evolution of Total Reserves during QE. The figure shows the evolution of reserves for all US Bank Holding Companies in our dataset ranging from 2006Q1 to 2014Q4. The shaded areas highlight the three rounds of QE.

Fed. Thus, regardless who the ultimate seller of securities is, large scale asset programs result in an increase in bank reserves. This is evident in Fig. 1 for our sample of banks. A notably sharper increase can be observed after QE3, which entailed the largest volume of purchased assets and, as a result, reserves creation.

This significant injection of reserves should affect banks' optimal portfolio allocation by changing their liquidity profile and duration of assets (Joyce and Spaltro, 2014; Kandrac and Schlusche, 2017). This might, in turn, induce banks to engage in additional lending (see Bianchi and Bigio, 2014, for a general equilibrium model). However, from the point of view of the amount of overall liquidity created in the banking sector, the composition of this increase in lending is important, as the example below will show.

We use a simple example to illustrate the confounding effects of $\mathrm{QE}$ on the liquidity created by banks. Liquidity creation captures the ability of banks to honour the obligations associated with liquid deposits, while having assets that are mainly illiquid, which reflects the classic liquidity transformation mechanism associated with modern fractional reserve banking. If, for instance, banks had to hold liquid assets to fully back every dollar of liquid deposits, then they would not really be involved in liquidity creation. Effectively, they would be acquiring liquid assets and holding them on behalf of their depositors, in a similar manner to a money market mutual fund.

Berger and Bouwman (2009) propose a measure that captures the extent of liquidity creation occurring via banks. ${ }^{7}$ Since liquidity creation implies that liquid deposits are used to finance illiquid assets such as loans, the measure assigns positive weights to all illiquid assets and liquid liabilities on and off the balance sheet. Banks can also "destroy" liquidity when illiquid liabilities and equity are transformed into liquid assets. As such, illiquid liabilities and liquid assets are assigned a negative weight. Moreover, since the degree of "liquidity" of a balance sheet item can differ, Berger and Bouwman (2009) classify assets and liabilities into three categories: liquid, semi-liquid and illiquid. For assets, this depends on how easy and fast a bank can sell them to meet liquidity demands, while for liabilities, on how easy customers can withdraw their funds from the bank. Weights are then assigned to reflect the idea that liquidity creation occurs when the bank finances relatively illiq-

\footnotetext{
7 Deep and Schaefer (2004) and Bai et al. (2018) propose different measures of liquidity creation, which we employ in the empirical strategy. For this example, we focus on the Berger and Bouwman (2009) index, which is simpler to illustrate numerically.
} 
Table 1

The impact of $\mathrm{QE}$ on liquidity creation: a simple example.

\begin{tabular}{|c|c|c|c|}
\hline \multicolumn{2}{|c|}{ Control bank } & \multicolumn{2}{|c|}{ Treated bank (Case 1) } \\
\hline Assets & Liabilities & Assets & Liabilities \\
\hline $\begin{array}{l}\text { C\&I Loans }+10 \\
L C=\frac{1}{2} \times 10+\frac{1}{2} \times\end{array}$ & Deposits +10 & $\begin{array}{l}\text { Reserves }+0 \\
M B S-100 \\
\text { C\&I Loans }+10 \\
\text { RE Loans }+100 \\
L C=\frac{1}{2} \times 10+\frac{1}{2}\end{array}$ & $10-0 \times 100=10$ \\
\hline \multicolumn{2}{|c|}{ Treated bank (Case 2) } & \multicolumn{2}{|c|}{ Treated bank (Case 3) } \\
\hline Assets & Liabilities & Assets & $\overline{\text { Liabilities }}$ \\
\hline $\begin{array}{l}\text { Reserves }+20 \\
M B S-100 \\
\text { C\&I Loans }+10 \\
\text { RE lending }+80 \\
L C=\frac{1}{2} \times 10+\frac{1}{2} \times 1\end{array}$ & $\begin{array}{l}\text { Deposits }+10 \\
-\frac{1}{2} \times 20+0 \times 80=0\end{array}$ & $\begin{array}{l}\text { Reserves }+0 \\
M B S-100 \\
\text { C\&I Loans }+60 \\
\text { RE lending }+50 \\
L C=\frac{1}{2} \times 60+\frac{1}{2}\end{array}$ & $\begin{array}{l}\text { Deposits }+10 \\
10+0 \times 50=35\end{array}$ \\
\hline \multicolumn{2}{|c|}{ Treated bank (Case 4) } & & \\
\hline Assets & $\overline{\text { Liabilities }}$ & & \\
\hline $\begin{array}{l}\text { Reserves }+0 \\
M B S-100 \\
\text { C\&I Loans }+0 \\
\text { RE lending }+110 \\
L C=\frac{1}{2} \times 0+\frac{1}{2} \times 10\end{array}$ & $+0 \times 110=5$ & & \\
\hline
\end{tabular}

uid assets with relatively liquid liabilities. Therefore, a weight of $1 / 2$ is applied to illiquid assets and liquid liabilities. Conversely, a weight of $-1 / 2$ is applied to liquid assets and illiquid liabilities and a weight of 0 is assigned to semi-liquid assets and liabilities. Appendix B discusses in detail the construction of this liquidity index.

The example in Table 1 shows how liquidity creation following the definition above can be affected by QE. In this example a "Treated bank" is one which sells MBS to the Fed for a value of, say, 100 , which results in a corresponding increase in Reserves by 100. The "Control bank" is not affected by the asset purchase program, but we assume all banks have an increase in deposits of 10 . Suppose the "Control bank" invests the 10 additional deposits in commercial and industrial (C\&I) loans. This leads to a liquidity creation of 10 by transforming the most liquid liabilities (deposits), which have a weight of $1 / 2$ in the Berger and Bouwman (2009) index, into the most illiquid assets (loans to enterprises), which are also assigned a weight of $1 / 2$. We then analyze three different scenarios, where the Treated banks also invest the additional deposits of 10 in C\&I loans, but differ in how they invest the new reserves created by $\mathrm{QE}$.

In Case 1, the Treated bank invests all the new reserves created by the policy in real estate (RE) loans. Since RE lending can be securitized and sold, it is considered a semi-liquid asset and is assigned a weight of 0 in the Berger and Bouwman (2009) index. The total amount of liquidity creation in this case is the same as the control bank. In Case 2, the bank keeps $20 \%$ of the reserves and uses the rest to fund RE loans. For this particular example, the liquidity created is zero and, as such, below that of the control bank. In Case 3 we assume that the treated bank uses all reserves to invest in RE lending and C\&I lending in equal shares. In this case, the level of liquidity created is greater than that of the control bank. Finally, Case 4 assumes that the QE program crowds out C\&I lending by making real estate loans more appealing. Here again, liquidity creation is lower as compared to the control bank.

As this simple example shows, whether banks exposed to $\mathrm{QE}$ create more liquidity in the banking sector depends crucially on the distribution of assets on their balance sheet after the policy. If QE crowded out C\&I lending, as shown in Chakraborty et al. (2020), we should expect that treated banks created less liquidity as compared to the control ones. If banks increase both real estate and industrial lending, the amount of liquidity created depends on the relative size of each asset class. As such, the effect of $Q E$ on liquidity creation is not a priori clear. ${ }^{8}$

\section{Data and identification strategy}

We obtain bank-level data from the Consolidated Financial Statements for Bank Holding Companies (BHCs) FR Y-9C quarterly reports, that are filled by BHC with at least $\$ 500$ million in total assets. ${ }^{9}$ Our sample consists of quarterly data from 2006:Q1 to 2014:Q4 and comprises of 7124 unique BHCs over this time frame. The number of BHCs varies across quarters due to different reporting requirements, with an average of 1200 BHCs reporting data in all quarters and 5500 BHCs reporting only bi-annually (in Q2 and Q4). ${ }^{10}$ Table 2 presents some descriptive statistics for key variables included in the dataset. We describe the construction and definitions of all variables in Appendix A.

Our main dependent variable is a measure of liquidity creation at the bank level. Berger and Bouwman (2009) propose four measures of liquidity creation: (i) cat fat, which classifies assets and liabilities based on their type (liquid, illiquid and semi-liquid) and

\footnotetext{
8 In the example above, we have assumed that the bank is the ultimate seller of securities to the Fed. If the ultimate seller is a bank customer, then deposits are also likely to rise. This would imply a similar ambiguous effect on liquidity creation. Such potential changes to bank deposits further motivates our empirical strategy that focuses on liquidity creation as opposed to only lending behaviour, as measures of liquidity creation will also account for the evolution of the liability side banks' balance sheets.

9 The FR Y-9C reports provide not only balance sheet data, but also capital positions, risk-weighted assets, securitization activities and off-balance sheet exposures, among others.The data is obtained from the Federal Reserve Bank of Chicago at https://www.chicagofed.org/applications/bhc/bhc-home.

10 Consolidated Report of Condition and Income (FR Y-9C) contains separate reporting for the parent company of large BHCs (FR Y-9LP) and parent company of small BHCs (FR Y-9SP). The number of observations varies from quarter to quarter because the Y-9SP is collected on a semiannual basis (in June and December). Since holding companies that file this report are included in those quarters, there is a significant increase in the number of observations for June and December. The first and third quarter only include banks that file the Y-9C and Y-9LP.
} 
Table 2

Summary Statistics.

\begin{tabular}{lcccccc}
\hline Variable & Mean & Standard Deviation & $\mathrm{p} 25$ & $\mathrm{p} 50$ & $\mathrm{p} 75$ & Observations \\
\hline Log (Assets) & 14.2 & 1.33 & 13.35 & 13.76 & 14.52 & 36,989 \\
Equity/assets & 0.1 & 0.05 & 0.08 & 0.09 & 0.11 & 36,989 \\
MBS/assets & 0.1 & 0.09 & 0.027 & 0.077 & 0.14 & 29,810 \\
MBS/securities & 0.45 & 0.29 & 0.21 & 0.47 & 0.68 & 29,761 \\
Securities/assets & 0.2 & 0.12 & 0.11 & 0.18 & 0.26 & 36,989 \\
Deposits/assets & 0.78 & 0.12 & 0.75 & 0.81 & 0.85 & 34,468 \\
Reserves/assets & 0.06 & 0.057 & 0.023 & 0.037 & 0.072 & 36,989 \\
Real estate lending/assets & 0.5 & 0.16 & 0.41 & 0.52 & 0.61 & 36,989 \\
C\&I loans/assets & 0.097 & 0.068 & 0.051 & 0.083 & 0.13 & 36,989 \\
Total lending/assets & 0.66 & 0.14 & 0.6 & 0.68 & 0.76 & 36,989 \\
Return on Assets (ROA) & 0.03 & 0.69 & 0.01 & 0.02 & 0.03 & 36,989 \\
Borrowings/ assets & 0.122 & 0.11 & 0.06 & 0.1 & 0.15 & 34,468 \\
\hline
\end{tabular}

Summary statistics recorded from 2006Q1 to 2014Q4 for all U.S. BHCs. All variables are at quarterly frequency. Variable definitions are provided in Appendix A.

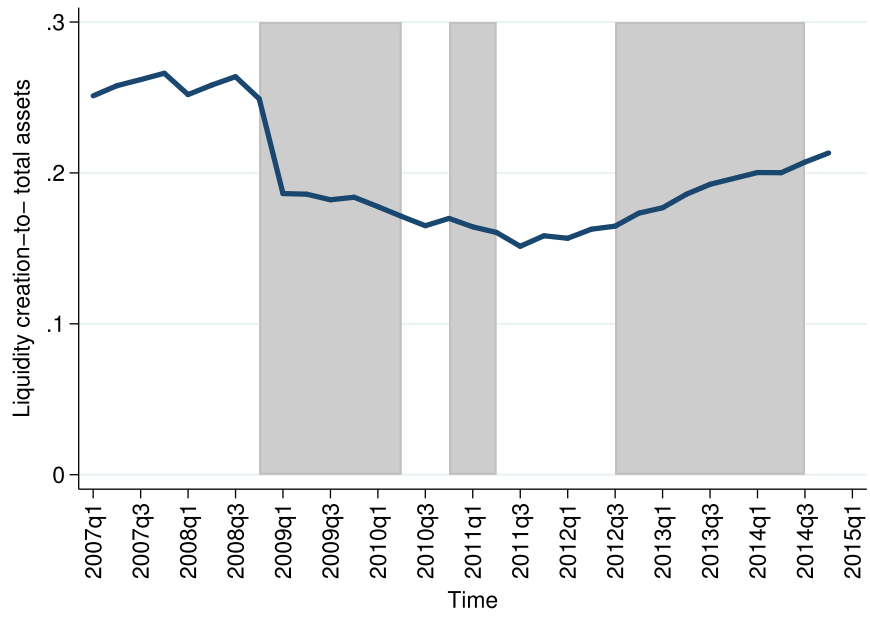

Fig. 2. Evolution of liquidity creation. The figure shows the average ratio of liquidity creation to total assets in our sample of banks. Shaded areas highlight the three episodes of QE.

includes off-balance sheet items; (ii) cat non-fat follows the same classification, but excludes any off-balance sheet items; (iii) mat fat defines assets and liabilities based on maturity/duration and includes off-balance sheet components and finally, (iv) mat non-fat includes a classification by maturity, but excludes off-balance sheet items. ${ }^{11}$ As the authors argue, the most comprehensive measure is the cat fat one, which will also be our main measure of liquidity creation. ${ }^{12}$ A description of the weights and construction of the index is presented in Appendix B.

Fig. 2 shows the ratio of liquidity creation to total assets over the sample period. Liquidity creation drops considerably in 2008Q4 and remains at low levels until 2012, when a sharp increase is noticed. This improvement in liquidity creation coincides with the Fed's third round of QE.

\subsection{Identification strategy}

Our identification strategy follows Rodnyansky and Darmouni (2017) and exploits the cross-sectional variation in MBS

\footnotetext{
11 Off-balance sheet activities, such as loan commitments and guarantees, allow customers to draw-down funds, and are considered important contributors to liquidity creation (Holmstrom and Tirole, 1997; Kashyap et al., 2002).

12 The Berger and Bouwman (2009) index of liquidity creation has been widely used to examine, among others, the role of bank capital (Horváth et al., 2014; Kim and Sohn, 2017), bank regulation and governance (Berger et al., 2016; Díaz and Huang, 2017; Huang et al., 2018), competition (Jiang et al., 2019) or monetary policy (Berger and Bouwman, 2017) on liquidity creation.
}

holdings across banks. This methodology relies on the assumption that banks that held more MBS on their balance sheet were more likely to be affected by the Fed's asset purchases. Several arguments support this claim. First, during the three waves of $\mathrm{QE}$, the Fed focused on easing the deterioration in the MBS market by lowering yields and increasing the prices of banks' current asset holdings, thereby improving the balance sheets of banks that held higher shares of mortgage-backed securities. This increase in prices of banks' assets could have improved their capital positions, which have been shown theoretically and empirically to be correlated with higher liquidity creation (Berger and Bouwman, 2009; Donaldson et al., 2018). Second, banks with more MBS sold to the Fed saw a higher increase in reserves, which should have shifted their loan supply (Kandrac and Schlusche, 2017).

We measure a bank's exposure to QE by the ratio of MBS-tototal assets. Following Rodnyansky and Darmouni (2017), we define as the treatment group banks in the highest $25 \%$ of the MBS-tototal assets distribution, while those in the lowest $25 \%$ are included in the control group. To minimize endogeneity, banks are classified according to their MBS-to-total assets ratio in 2007:Q4, which is more than half a year before QE1. We also consider several alternative definitions for the assignment to treatment and control groups. First, we classify banks in the top decile of the distribution of MBS-to-total assets into the treatment group, and those in the bottom decile in the control. Second, we employ the ratio of MBS-to-total assets in 2007:Q4, which allows for an analysis of the entire sample of banks.

As shown in Rodnyansky and Darmouni (2017), the classification of banks into treatment and control groups is rather stable over time, as the level of MBS-to-total assets is fairly sticky. This alleviates the concern that banks might respond strategically to the LSAPs by increasing their holdings of mortgage-based securities. Nonetheless, it might be that banks in the treatment and control groups are systematically different along a number of characteristics. To check this, we perform simple cross-sectional correlations between the treatment assignment variable and a number of bank characteristics. The results are presented in Table 3 , where Treat $_{i}$ is the treatment definition based on quartiles (column 1), Treat $_{i}^{D}$ the one based on deciles (column 2), and $\left(\frac{M B S}{A s s e t s}\right)_{i}$ is the ratio of MBS-to-total assets in 2007:Q4 (column 3).

These simple correlations suggest that banks that hold more mortgage backed securities tend to be different than control banks along several characteristics, which include size (log of assets), profitability (Net income to total assets), leverage (Equity to assets), and the ratio of securities to assets. As such, treated banks are typically larger, more leveraged, less profitable and hold more securities as a share of total assets. Importantly, however, treated 
Table 3

Correlations between Treatment Group and Bank Characteristics

\begin{tabular}{|c|c|c|c|c|c|c|}
\hline & \multicolumn{2}{|c|}{$\begin{array}{c}\text { Treat }_{i} \\
\text { (1) }\end{array}$} & \multicolumn{2}{|c|}{$\begin{array}{c}\text { Treat }_{i}^{D} \\
(2)\end{array}$} & \multicolumn{2}{|c|}{$\begin{array}{c}\left(\frac{M B S}{A S s e t s}\right)_{i} \\
(3)\end{array}$} \\
\hline & coeff & $\mathrm{SE}$ & coeff & SE & coeff & SE \\
\hline Log(Assets) & $0.082^{* * *}$ & {$[0.017]$} & $0.050^{*}$ & {$[0.029]$} & $0.010^{* * *}$ & {$[0.002]$} \\
\hline Tier 1 Capital Ratio & -0.011 & {$[0.008]$} & -0.004 & {$[0.009]$} & 0.001 & {$[0.000]$} \\
\hline Securities/Assets & $2.644^{* * *}$ & {$[0.295]$} & $2.219^{* * *}$ & {$[0.438]$} & $0.464^{* * *}$ & {$[0.035]$} \\
\hline Equity/Assets & 0.678 & {$[0.806]$} & -0.195 & [1.185] & $-0.232^{* *}$ & [0.105] \\
\hline Lending/Assets & 0.334 & {$[0.272]$} & 0.103 & {$[0.388]$} & $0.070^{* *}$ & [0.029] \\
\hline Net income/Total Assets & $-54.09^{* * *}$ & [9.564] & $-49.98^{* * *}$ & [15.42] & -1.561 & [1.194] \\
\hline Observations & 472 & & 189 & & 938 & \\
\hline R-squared & 0.440 & & 0.519 & & 0.414 & \\
\hline
\end{tabular}

The table shows correlations between the treatment condition and bank characteristics in 2007Q1. Treat $_{i}$ is a dummy that takes the value one for banks in the $75^{\text {th }}$ percentile of the MBS-to-total assets ratio, and zero for banks in the $25^{\text {th }}$ percentile. Treat ${ }_{i}^{D}$ is a dummy that takes the value one for banks in the $90^{\text {th }}$ percentile of the MBS-to-total assets ratio, and zero for banks in the $10^{\text {th }}$ percentile. $\left(\frac{M B S}{\text { Assets }}\right)_{i}$ is the ratio of MBS to Total assets in 2007:Q4. Robust standard errors in brackets. ${ }^{* *},{ }^{* *},{ }^{*}$ represent significance at the $1 \%, 5 \%$ and $10 \%$, respectively.

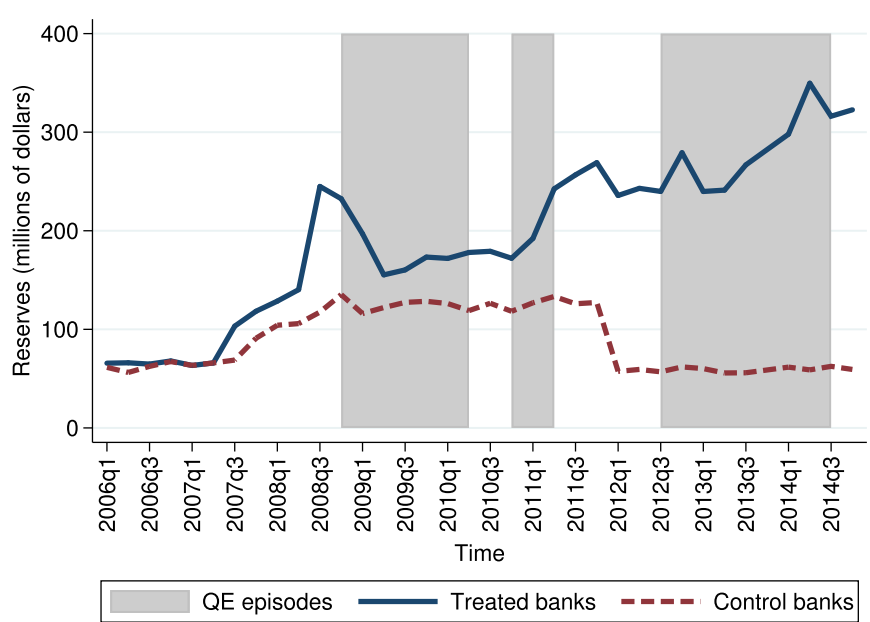

Fig. 3. Evolution of total reserves for treated and control banks. The figure shows the evolution of reserves for treated and control banks. Treated banks are banks in the top $75^{\text {th }}$ percentile of MBS-to-total assets ratio in 2007Q4, while control are in the bottom $25^{\text {th }}$ percentile. Shaded areas highlight the three episodes of QE.

banks do not have a higher share of lending to total assets prior to the implementation of $\mathrm{QE}$.

The underlying argument behind our identification strategy is that banks with a higher share of mortgage-backed securities in total assets prior to $\mathrm{QE}$ (treated banks) benefited more from the program. Fig. 3 shows the reserve accumulation by treated and control banks throughout the sample period. Clearly, we observe that banks in the treatment group witnessed a higher surge in reserves relative to control banks, potentially as a result of $\mathrm{QE}$.

This differential evolution of reserves can be explained in two ways. First, treated banks who held more MBS before QE also sold more MBS to the Fed afterwards. Fig. 4, which shows the evolution of the MBS-to-total assets of treated and control banks separately, supports this argument: MBS holdings of treated banks (solid line) start to decline immediately after the implementation of $\mathrm{QE}$, while control banks (dashed line) see an increase. Second, as most of the sales of MBS to the Fed during QE actually came from non-bank entities, the pattern in Fig. 3 could also be the result of treated banks having more clients that sold MBS to the Fed. Since only banks hold accounts with the Fed, sales of securities to the central bank by any institution transits through the balance sheet of a bank: the Fed credits banks' reserve accounts, which leads to

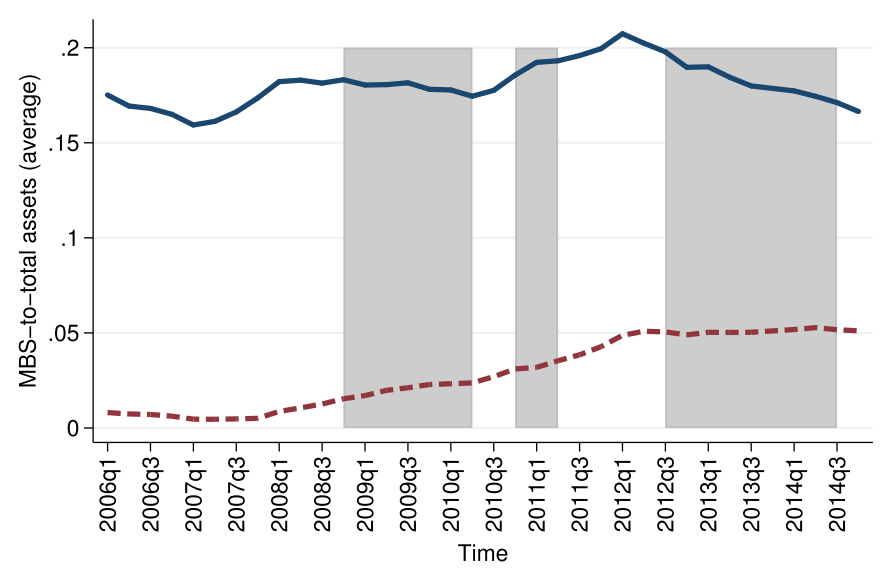

Fig. 4. MBS-to-total assets for treated and control banks. The figure maps the evolution of the ratio of MBS-to-assets for treated and control banks. Treated banks are banks in the top $75^{\text {th }}$ percentile of MBS-to-total assets ratio in 2007Q4, while control are in the bottom $25^{\text {th }}$ percentile. Shaded areas highlight the three episodes of QE.

a build up of bank reserves and an increase in bank customers' deposits on the liabilities side of the bank's balance sheet. Fig. 5 shows that customer deposits did increase in the sample of treated banks, especially after QE2. That being said, it is clear that no single mechanism explains why banks with higher MBS were more affected by the Fed MBS purchases, rather this can be explained through a variety of distinct direct and indirect purchase mechanisms.

Our identification strategy exploits the cross-sectional variation in banks' exposure to the Fed's large-scale asset purchases via difference-in-differences regressions, as follows:

$Y_{i, j, t}=\alpha_{i}+\beta_{j, t}+\theta^{\prime}$ Treat $_{i} \times Q E_{\tau}+\gamma^{\prime} Q E_{\tau}+\eta$ Treat $_{i}+\delta^{\prime} X_{i, t}+\epsilon_{i, t}$,

where $Y_{i, j, t}$ is a measure of liquidity creation by bank $i$ in state $j$ at time $t$. $Q E \tau=[Q E 1, Q E 2, Q E 3]$ is a vector of time dummies corresponding to the introduction of each QE episode. QE1 takes the value 1 during the period 2008:Q4 (November) - 2010:Q2 (June), QE2 from 2010:Q4 (November) - 2011:Q2 (June) and QE3 from 2012:Q3 (September) to 2014:Q3 (October), respectively. Treat $_{i}$ is an indicator variable and takes the value of 1 if a bank belongs to the treatment group and 0 if the bank belongs to the control 


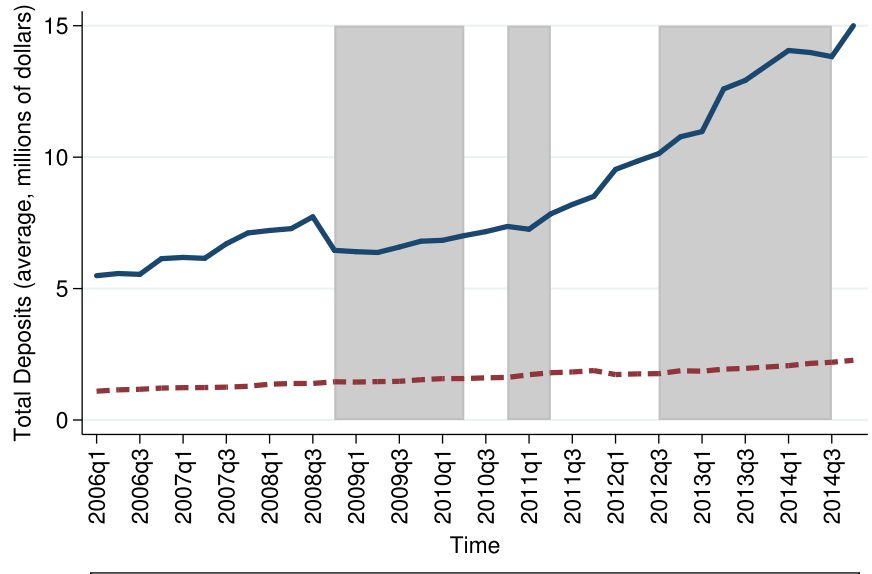

QE episodes Treated banks =-ー= Control banks

Fig. 5. Total deposits-to-total assets for treated and control banks. The figure shows the distribution of deposits-to-assets for treated and control banks. Treated banks are banks in the top $75^{\text {th }}$ percentile of MBS-to-total assets ratio, while control are in the bottom $25^{\text {th }}$ percentile. Shaded areas highlight the three episodes of $\mathrm{QE}$.

group. Treat ${ }_{i} \times Q E \tau$ is an interaction term between a bank's treatment status and time dummies corresponding to each QE episode. The vector $\theta$ captures our coefficients of interest, namely the differential impact of each round of $\mathrm{QE}$ on liquidity creation in the treated as compared to the control group.

Vector $X_{i, t}$ includes a series of bank-level controls that capture differences in the scale and financial position of banks that might affect their lending activity (see Cornett et al., 2011; Berger and Bouwman, 2013; Chakraborty et al., 2020). Particularly, we control for bank size, capital, profitability and leverage, which have been shown to affect loan supply and are also correlated with the treatment condition (see, for example, Kashyap and Stein, 2000). We add bank fixed effects to remove all time-invariant differences across banks. Bank fixed effects also capture the average difference in liquidity creation between treated and control banks across the sample period. Our baseline specification also includes state-time fixed effects $\left(\beta_{j, t}\right)$ to control for unobserved time-varying shocks at the state-level that might affect both the demand and supply of bank loans. ${ }^{13}$ This allows us to control closely to macroeconomic conditions and obtain identification between banks in the same state. The inclusion of this large set of fixed effects also absorbs the coefficients of the three rounds of $\mathrm{QE}\left(\gamma^{\prime}\right)$ and the treatment dummy $(\eta)$ and reduces concerns of omitted variable bias.

\section{Results}

This section examines the impact of Federal Reserve's LSAP on the lending behaviour of banks and liquidity creation. First, we consider the effects of the three rounds of $\mathrm{QE}$ on lending, distinguishing between total lending, real estate (RE) loans and commercial and industrial (C\&I) loans. Second, we present our main results pertaining to liquidity creation. Lastly, we present a series of robustness tests of our main results.

\subsection{The impact of $Q E$ on bank lending}

Motivated by previous literature, we first revisit the impact of QE on bank lending in our sample of banks. As discussed in the Introduction, QE could impact lending through a classical bank lend-

\footnotetext{
${ }^{13}$ We also show the robustness of all results when including only year-quarter fixed affects.
}

ing channel as the new reserves and/or deposits resulting from the policy lead to a shift in the loan supply. There are also several reasons to believe that financial institutions might respond to the policy by increasing some types of loans and not others. In particular, previous work points to a strong impact of $\mathrm{QE}$ on real estate lending. This could be due to the fact that banks with higher MBS shares (our treatment group) are more active in the mortgage market and more exposed to the housing market in general (Luck and Zimmermann, 2020). As such higher MBS shares could reflect a different business model, which implies that, as the prospects of the housing market improved due to $\mathrm{QE}$, these banks benefited more and were more likely to engage in mortgage origination or refinancing. For example, Di Maggio et al. (2020) show that the type of assets purchased by the Fed matters for the type of loans originated by banks. Particularly, they find that banks mainly issued GSE-guaranteed mortgages, which were eligible for sale to the Federal Reserve during QE1, and less so non-eligible mortgages.

To study the heterogeneous impact of $\mathrm{QE}$ on different types of loans, we follow closely the empirical strategy in Rodnyansky and Darmouni (2017) who use the Call Reports (FFIEC 031) data for a larger sample of BHCs over the period 2008-2014. We thus estimate the baseline difference-in-difference regressions in Eq. (1), where we replace $Y_{i, t}$ with the logarithm of total lending, real estate lending and commercial and industrial lending, respectively. We employ two treatment definitions: (i) Treat $_{i}$ that takes the value of 1 if the bank is in the top $75^{\text {th }}$ percentile of MBS-tototal assets in 2007Q4 and 0 if the bank is in the bottom $25^{\text {th }}$ percentile, and (ii) $\left(\frac{M B S}{A s s e t s}\right)_{i}$ that is the ratio of MBS-to-total assets in 2007Q4.

Furthermore, as the classification of banks by MBS holdings is correlated with bank size (see Table 3), we employ matching techniques to further reduce biases that stem from the endogeneous determination of MBS holdings (see also Rodnyansky and Darmouni, 2017). Specifically, we match our treated and control groups by size using propensity scores based on a logit model that relates the probability of being assigned to the treated group to the log of total assets in 2007Q4. We then employ this propensity score to re-weight treatment and control groups such that the distribution of bank size looks the same in both groups. This is done using the conditional probability of being in the treated group, $\hat{\lambda}$, to compute a weight as the odds ratio $\hat{\lambda} /(1-\hat{\lambda})$ (see Nichols, 2007).

The results are presented in Table 4 . Columns (1)-(2) pertain to total lending, columns (3)-(4) to RE lending and (5)-(6) to C\&I loans, respectively. Across both definitions of treated and control banks, we find that treated banks expanded lending more than control banks. For total and RE lending these differential effects are robust across all specifications for the first and third round of $\mathrm{QE}$, while the effect on corporate lending is robustly estimated only during QE3. These results are in line with previous research that shows a stronger impact of QE1 and QE3 on overall lending, given that the Federal Reserve purchased MBS only during these rounds of QE, and not in the second (Rodnyansky and Darmouni, 2017; Luck and Zimmermann, 2020; Kurtzman et al., 2018). ${ }^{14}$ Our results also point to an overall stronger impact of $\mathrm{QE}$ on mortgage lending as compared to commercial loans, which can have implications for liquidity creation. We turn to this next.

\footnotetext{
14 Appendix Table 9, replicates more closely the empirical strategy in Rodnyansky and Darmouni (2017) (see Table 6 in their paper), where we also control for the interaction between dummies capturing the three rounds of $\mathrm{QE}$ and the bank level controls to allow for possible heterogeneous responses to the intervention by BHCs. This specification also includes only year-quarter fixed effects as opposed to state-time ones. The results are qualitatively similar.
} 
Table 4

The impact of $\mathrm{QE}$ on bank lending.

\begin{tabular}{|c|c|c|c|c|c|c|}
\hline & \multicolumn{2}{|c|}{ Total Lending } & \multicolumn{2}{|c|}{ Real Estate Loans } & \multicolumn{2}{|c|}{ C\&I Loans } \\
\hline & (1) & (2) & (3) & (4) & (5) & (6) \\
\hline QE1 $\times$ Treat $_{i}$ & $\begin{array}{l}0.027^{* * *} \\
(0.009)\end{array}$ & & $\begin{array}{l}0.077^{* * *} \\
(0.020)\end{array}$ & & $\begin{array}{l}0.012 \\
(0.015)\end{array}$ & \\
\hline QE2 $\times$ Treat $_{i}$ & $\begin{array}{l}-0.059^{* * *} \\
(0.017)\end{array}$ & & $\begin{array}{l}0.016 \\
(0.018)\end{array}$ & & $\begin{array}{l}0.007 \\
(0.019)\end{array}$ & \\
\hline QE3 $\times$ Treat $_{i}$ & $\begin{array}{l}0.032^{* * *} \\
(0.006)\end{array}$ & & $\begin{array}{l}0.043^{* * *} \\
(0.009)\end{array}$ & & $\begin{array}{l}0.038^{* *} \\
(0.018)\end{array}$ & \\
\hline$Q E 1 \times\left(\frac{M B S}{\text { Assets }}\right)_{i}$ & & $\begin{array}{l}0.055 \\
(0.046)\end{array}$ & & $\begin{array}{l}0.207^{* *} \\
(0.097)\end{array}$ & & $\begin{array}{l}0.047 \\
(0.097)\end{array}$ \\
\hline$Q E 2 \times\left(\frac{M B S}{\text { Assets }}\right)_{i}$ & & $\begin{array}{l}-0.083 \\
(0.091)\end{array}$ & & $\begin{array}{l}0.126 \\
(0.087)\end{array}$ & & $\begin{array}{l}0.218^{*} \\
(0.111)\end{array}$ \\
\hline$Q E 3 \times\left(\frac{M B S}{\text { Assets }}\right)_{i}$ & & $\begin{array}{l}0.339 * * * \\
(0.044)\end{array}$ & & $\begin{array}{l}0.356^{* * *} \\
(0.057)\end{array}$ & & $\begin{array}{l}0.383^{* * *} \\
(0.113)\end{array}$ \\
\hline Observations & 14,451 & 29,068 & 14,405 & 29,021 & 14,421 & 29,013 \\
\hline R-squared & 0.996 & 0.999 & 0.987 & 0.996 & 0.967 & 0.992 \\
\hline Bank-level Controls & Yes & Yes & Yes & Yes & Yes & Yes \\
\hline State-time Fixed Effects & Yes & Yes & Yes & Yes & Yes & Yes \\
\hline Bank Fixed Effects & Yes & Yes & Yes & Yes & Yes & Yes \\
\hline
\end{tabular}

The dependent variable in Columns (1)-(2) is log of Total lending, in Columns (3)-(4) is the log of real estate loans and in Column (5)-(6) is the log of commercial and industrial loans. Treat $t_{i}$ is a dummy that takes the value one for banks in the $75^{\text {th }}$ percentile of the MBS-to-total assets ratio, and zero for banks in the $25^{\text {th }}$ percentile. $\left(\frac{M B S}{A s s e t s}\right)_{i}$ is the ratio of MBS to Total assets in 2007Q4. QE1,QE2,QE3 are dummies for each $\mathrm{OE}$ wave. Bank-level controls include the log of total assets, Tier 1 capital ratio, the net income to total assets and equity over assets. Constant terms included, but not reported. Robust standard errors in parentheses. ${ }^{* * *},{ }^{* *},{ }^{*}$ represent significance at the $1 \%, 5 \%$ and $10 \%$, respectively.

\subsection{QE and bank liquidity creation}

Our main empirical specification estimates Eq. (1) using the Berger and Bouwman (2009) liquidity creation index scaled by total assets as the dependent variable. The results are presented in Table 5. We employ three treatment variables that classify banks based on quartiles, deciles and the continuous measure of MBS-tototal assets.

As before, the main variables of interest are the interaction terms between the QE time dummies and banks' treatment status. Columns (1)-(3) control for two-way fixed effects at the state-time level, which capture all time-varying aggregate demand factors at the state level and allow us to obtain identification from comparing banks in the same state in a given year-quarter. Columns (4)(6) show the robustness when controlling for year-quarter fixed effects only. ${ }^{15}$

Overall, our results suggest that treated banks created a disproportionally larger amount of liquidity in the banking sector. However, this result is robustly estimated across all specifications only for the third round of $\mathrm{QE}$. With the ratio of liquidity creation to total assets as the dependent variable and the interaction between a QE dummy and a treatment dummy as the independent, the estimates in columns (1) and (3) suggest that, during QE3, treated banks created close to $4 \%$ more liquidity relative to their size as compared to the control group.

Coupled, the results in Tables 4 and 5 suggest that, while banks with higher MBS/Total Assets were characterized by a disproportionally higher level of lending during both QE1 and QE3, this increase in lending resulted in a higher liquidity creation only during QE3. This implies that, during the first round of $\mathrm{QE}$, treated banks disproportionally created assets that are less illiquid, such as RE loans, which points to a weaker impact of the policy on the real economy.

\footnotetext{
15 Fig. 10 shows the coefficient estimates of the same regressions as Table 5 where matching based on propensity scores, as outlined above, is applied.
}

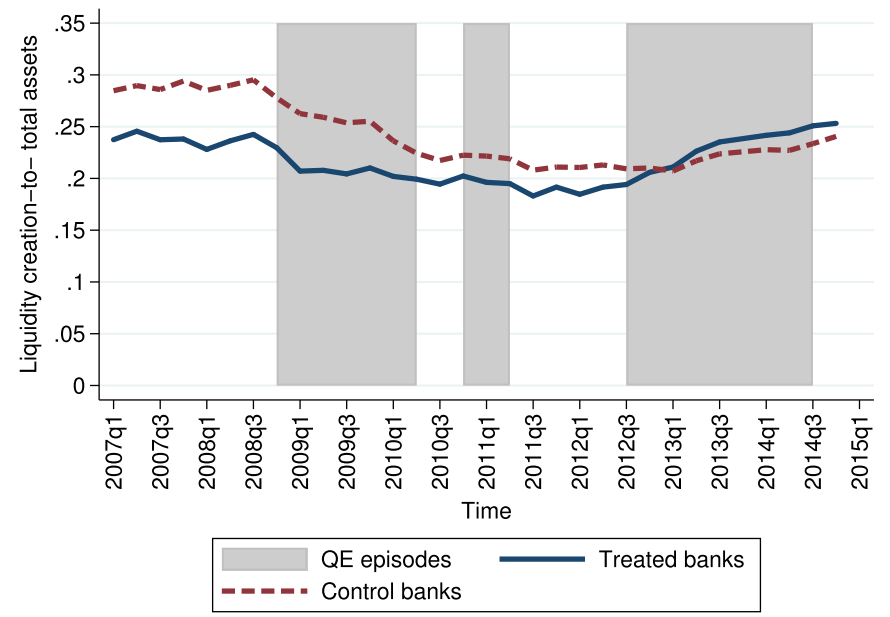

Fig. 6. Liquidity creation for treated and control banks. Treated banks are those in the $75^{\text {th }}$ percentile of MBS-to-assets ratio in $2007 \mathrm{Q} 4$, while control those in the $25^{\text {th }}$ percentile. Shaded areas highlight the three episodes of QE.

\subsection{Timing of the effects}

A plausible identification rests on the fact that the differential effects documented thus far are not driven by preexisting trends whereby treated banks create a significantly higher level of liquidity to total assets even prior to the introduction of the different rounds of $\mathrm{QE}$. In this subsection, we provide further evidence supporting this identifying assumption.

First, Fig. 6 shows the evolution of the average liquidity creation to total assets by treated and control banks, where treated banks are those in the $75^{\text {th }}$ percentile of MBS-to-assets ratio in 2007Q4, while control are those in the $25^{\text {th }}$ percentile, respectively. It shows that the measure of liquidity creation follows similar trends in the pre-QE period for both groups of banks, followed by a significant decline at the start of the 2008 Global financial crisis, as already documented in Fig. 2. Moreover, the ratio 
Table 5

The impact of $\mathrm{QE}$ on bank liquidity creation.

\begin{tabular}{|c|c|c|c|c|c|c|}
\hline & \multicolumn{6}{|c|}{ Liquidity creation to total assets } \\
\hline & (1) & $(2)$ & (3) & (4) & (5) & $(6)$ \\
\hline$Q E 1 \times$ Treat $_{i}$ & $\begin{array}{l}0.010^{* *} \\
(0.005)\end{array}$ & & & $\begin{array}{l}0.075 \\
(0.047)\end{array}$ & & \\
\hline QE2 $\times$ Treat $_{i}$ & $\begin{array}{l}0.019 * * \\
(0.007)\end{array}$ & & & $\begin{array}{l}0.065^{* *} \\
(0.031)\end{array}$ & & \\
\hline QE3 $\times$ Treat $_{i}$ & $\begin{array}{l}0.036^{* * * *} \\
(0.005)\end{array}$ & & & $\begin{array}{l}0.063 * * * \\
(0.020)\end{array}$ & & \\
\hline$Q E 1 \times\left(\frac{M B S}{\text { Assets }}\right)_{i}$ & & $\begin{array}{l}-0.043 \\
(0.049)\end{array}$ & & & $\begin{array}{l}0.057 \\
(0.057)\end{array}$ & \\
\hline$Q E 1 \times\left(\frac{M B S}{\text { Assets }}\right)_{i}$ & & $\begin{array}{l}0.054 \\
(0.072)\end{array}$ & & & $\begin{array}{l}0.153^{* *} \\
(0.077)\end{array}$ & \\
\hline$Q E 1 \times\left(\frac{M B S}{\text { Assets }}\right)_{i}$ & & $\begin{array}{l}0.235^{* * *} \\
(0.051)\end{array}$ & & & $\begin{array}{l}0.299 * * * \\
(0.114)\end{array}$ & \\
\hline$Q E 1 \times$ Treat $_{i}^{D}$ & & & $\begin{array}{l}0.018 \\
(0.012)\end{array}$ & & & $\begin{array}{l}0.109 \\
(0.068)\end{array}$ \\
\hline$Q E 1 \times$ Treat $_{i}^{D}$ & & & $\begin{array}{l}0.029 * \\
(0.017)\end{array}$ & & & $\begin{array}{l}0.089 * \\
(0.047)\end{array}$ \\
\hline$Q E 1 \times$ Treat $_{i}^{D}$ & & & $\begin{array}{l}0.037^{* * *} \\
(0.013)\end{array}$ & & & $\begin{array}{l}0.076^{* * *} \\
(0.029)\end{array}$ \\
\hline Observations & 14,460 & 29,077 & 5488 & 14,620 & 29,181 & 5872 \\
\hline R-squared & 0.929 & 0.948 & 0.954 & 0.128 & 0.039 & 0.201 \\
\hline Controls & Yes & Yes & Yes & Yes & Yes & Yes \\
\hline State-time Fixed Effects & Yes & Yes & Yes & No & No & No \\
\hline Year-quarter fixed effects & No & No & No & Yes & Yes & Yes \\
\hline Bank Fixed Effects & Yes & Yes & Yes & Yes & Yes & Yes \\
\hline
\end{tabular}

The dependent variable is ratio of liquidity creation to total assets. Treat $_{i}$ is a dummy that takes the value one for banks in the $75^{\text {th }}$ percentile of the MBS-to-total assets ratio, and zero for banks in the $25^{\text {th }}$ percentile. Treat $_{i}^{D}$ is a dummy that takes the value one for banks in the $90^{\text {th }}$ percentile of the MBSto-total assets ratio, and zero for banks in the bottom $10^{\text {th }}$ percentile. $\left(\frac{M B S}{A s s e t s}\right)_{i}$ is the ratio of MBS-to-total assets in 2007Q4. QE1, QE2, QE3 are dummies for each QE wave. Bank-level controls include the log of total assets, Tier 1 capital ratio, the net income to total assets and equity over assets. Robust standard errors in parentheses. ${ }^{* * *},{ }^{* *},{ }^{*}$ represent significance at the $1 \%, 5 \%$ and $10 \%$, respectively.

Table 6

Alternative identification strategy.

\begin{tabular}{lllll}
\hline & \multicolumn{3}{l}{ Liquidity creation to total assets } \\
\cline { 2 - 5 } & $(1)$ & $(2)$ & $(3)$ & $(4)$ \\
\hline MBS purchases $_{t-1} \times$ Treat $_{i}$ & $\begin{array}{l}0.003^{* * *} \\
(0.001)\end{array}$ & $\begin{array}{l}0.002^{* * *} \\
(0.000)\end{array}$ & & \\
Treasury purchases & & & \\
& $\begin{array}{l}0.002^{* *} \\
\text { Treat }\end{array}$ & $0.001^{* * *}$ & & \\
& $(0.001)$ & $(0.000)$ & & \\
MBS purchases $_{t-1} \times$ Treat $_{i}^{D}$ & & & $0.003^{* *}$ & $0.002^{* *}$ \\
& & & $(0.001)$ & $(0.001)$ \\
Treasury purchases & & & 0.001 & 0.000 \\
& & & $(0.002)$ & $(0.001)$ \\
Observations & & & 4697 & 4337 \\
R-squared & 11,680 & 11,492 & 0.035 & 0.962 \\
Controls & 0.057 & 0.940 & Yes & Yes \\
Bank Fixed Effects & Yes & Yes & Yes & Yes \\
Year-Quarter Fixed Effects & Yes & Yes & Yes & No \\
State time fixed effects & Yes & No & No & Yes \\
\hline
\end{tabular}

The dependent variable is the Berger and Bouwman (2009) liquidity creation measure to total assets. $M B S_{t-1}$ and $T S Y_{t-1}$ are the of log amount of mortgage-backed securities Treasury securities purchased by the Fed during 2008-2014. Treat $_{i}$ is a dummy equal 1 for banks in the $75^{\text {th }}$ percentile of MBS-to-assets ratio in 2007Q4, and zero for those in the $25^{\text {th }}$ percentile. Treat $t_{i}^{D}$ is a dummy equal 1 for banks in the $90^{\text {th }}$ percentile of MBS-to-assets ratio in 2007Q4, and zero for those in the $10^{\text {th }}$ percentile. Bank-level controls include: logarithm of total assets, Tier 1 capital ratio, deposits to assets ratio, equity to assets ratio and return on assets. Constant term included but not reported. Robust standard errors in parentheses. ${ }^{* * *},{ }^{* *},{ }^{*}$ represent significance at the $1 \%, 5 \%$ and $10 \%$, respectively.

of LC/TA is actually higher in the control group for most of the period. However, a significant change in trend is observed following the start of the last round of QE in $2012 \mathrm{Q} 3$ when treated banks see a larger increase in liquidity creation. This confirms the effects documented in Table 5. It also suggests that the effects of the policy are rather immediate and do not follow a significant time lag.

To further investigate the timing of effects, we estimate the following model where, instead of dummy variables capturing the full period of the three $\mathrm{QE}$ rounds, we interact the treatment variable with an indicator for each quarter. Precisely, the specification tested is:

$L C / T A_{i, j, t}=\alpha_{i}+\beta_{j, t}+\sum_{t} \gamma_{t} D_{t}+\sum_{t} \theta_{t} D_{t} \times$ Treat $_{i}+\delta^{\prime} X_{i, t}+\epsilon_{i, t}$,

where $D_{t}$ is a vector of dummy variables for each $t \in$ $\{2007 Q 1,2007 Q 2, \ldots, 2014 Q 4\} \backslash\{2008 Q 3\}$, with $2008 Q 3$ taken as the benchmark period. Treat ${ }_{i}$ a dummy that takes the value one for banks in the $75^{\text {th }}$ percentile of the MBS-to-total assets ratio, and zero for banks in the $25^{\text {th }}$ percentile. Fig. 7 shows a plot of the estimated coefficients of $\hat{\theta}_{t}$ in Eq. (2). Similar to the patterns observed thus far, it confirms that treated banks had a significantly larger LC/TA in the quarter following the start of QE3, and not before.

\subsection{Alternative identification strategy}

Chakraborty et al. (2020) investigate the impact of the Fed's LSAPs on bank lending and firm investment using an alternative identification strategy. They employ as independent variable the actual amount of MBS and treasury securities purchased as opposed to time dummies corresponding to the introduction of each $\mathrm{QE}$ episode. Fig. 8 shows these quantities in each quarter, and clearly identifies the start of the different QE rounds and how this alternative measure captures the scale of each QE program. We follow their approach and interact the log amount of MBS and trea- 


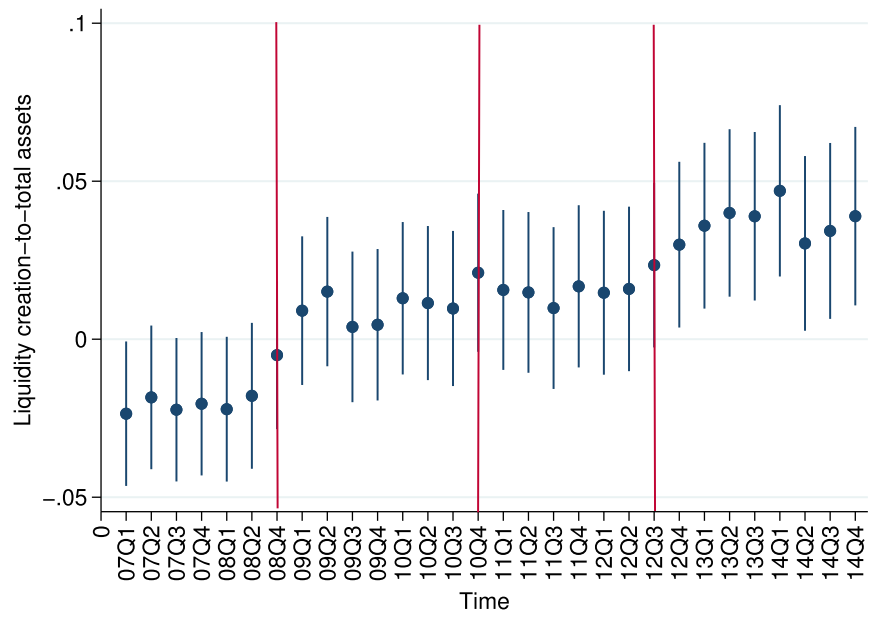

Fig. 7. Timing of effects. The figure shows coefficient plots for the parameters $\theta_{t}$ in Eq. 2 with 95\% confidence intervals. The vertical lines indicate the start of each episode of quantitative easing.

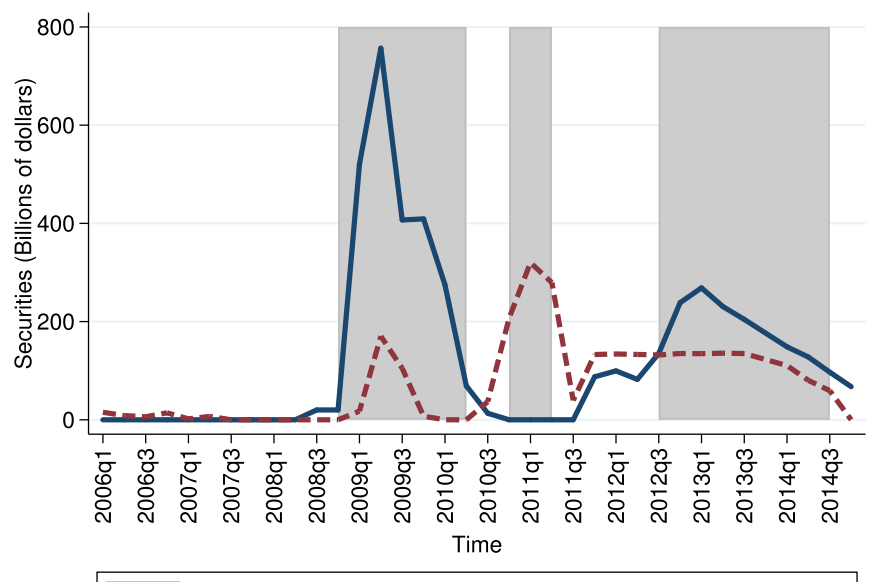

Fig. 8. Quarterly purchase of MBS and Treasury securities by the Fed. The figure shows the quarterly amount of mortgage-backed securities (solid line) and Treasury securities (dashed line) purchased by the Fed. The shaded areas indicate the three rounds of quantitative easing.

sury purchases by the Fed in the last quarter of the previous year $(t-1)$ with our treatment dummies.

Table 6 presents the results using this alternative independent variable interacted with the treatment variables based on quartiles and deciles, respectively. The most robust evidence points to an impact on liquidity creation following MBS purchases, and less so following purchases of T-bills, which mainly occurred during QE2. This is in line with our previous results and Chakraborty et al. (2020), who also find an impact on lending mainly following MBS purchases. Yet, unlike Chakraborty et al. (2020), who find that real estate mortgages crowded out commercial loans, we find a consistently positive impact on liquidity creation.

\subsection{Liquidity mismatch index}

Bai et al. (2018) propose a more complex measure of liquidity creation, called the Liquidity Mismatch Index (LMI). Similar to the Berger and Bouwman (2009) measure, the LMI captures the liquidity of both asset (market liquidity) as well as liability side (funding liquidity). Market liquidity refers to the ease with which
Table 7

LMI index (Bai et al., 2018).

\begin{tabular}{|c|c|c|c|}
\hline & (1) & (2) & (3) \\
\hline QE1 $\times$ Treat $_{i}$ & $\begin{array}{l}0.016 \\
(0.042)\end{array}$ & & \\
\hline QE2 $\times$ Treat $_{i}$ & $\begin{array}{l}0.057 \\
(0.062)\end{array}$ & & \\
\hline QE3 $\times$ Treat $_{i}$ & $\begin{array}{l}0.099 * * \\
(0.045)\end{array}$ & & \\
\hline$Q E 1 \times\left(\frac{M B S}{\text { Assets }}\right)_{i}$ & & $\begin{array}{l}0.031 \\
(0.156)\end{array}$ & \\
\hline$Q E 2 \times\left(\frac{M B S}{\text { Assets }}\right)_{i}$ & & $\begin{array}{l}0.318 \\
(0.227)\end{array}$ & \\
\hline$Q E 3 \times\left(\frac{M B S}{\text { Assets }}\right)_{i}$ & & $\begin{array}{l}0.407^{* *} \\
(0.162)\end{array}$ & \\
\hline$Q E 1 \times$ Treat $_{i}^{D}$ & & & $\begin{array}{l}0.033 \\
(0.106)\end{array}$ \\
\hline$Q E 2 \times$ Treat $_{i}^{D}$ & & & $\begin{array}{l}0.138 \\
(0.156)\end{array}$ \\
\hline$Q E 3 \times$ Treat $_{i}^{D}$ & & & $\begin{array}{l}0.020 \\
(0.113)\end{array}$ \\
\hline Observations & 14,460 & 29,077 & 5488 \\
\hline R-squared & 0.493 & 0.496 & 0.519 \\
\hline Controls & Yes & Yes & Yes \\
\hline State-time Fixed Effects & Yes & Yes & Yes \\
\hline Bank Fixed Effects & Yes & Yes & Yes \\
\hline
\end{tabular}

The dependent variable is the Bai et al. (2018) LMI index. Treat $_{i}$ is a dummy that takes the value one for banks in the $75^{\text {th }}$ percentile of the MBS-to-total assets ratio, and zero for banks in the $25^{\text {th }}$ percentile. Treat ${ }_{i}^{D}$ is a dummy that takes the value one for banks in the $90^{\text {th }}$ percentile of the MBS-to-total assets ratio, and zero for banks in the bottom $10^{\text {th }}$ percentile. QE1, QE2, QE3 are dummies for each QE wave. Bank-level controls include: logarithm of total assets, Tier 1 capital ratio, deposits to assets ratio, equity to assets ratio and return on assets. Constant term included but not reported. Robust standard errors in parentheses. ${ }^{* * *},{ }^{* *},{ }^{*}$ represent significance at the $1 \%, 5 \%$ and $10 \%$, respectively.

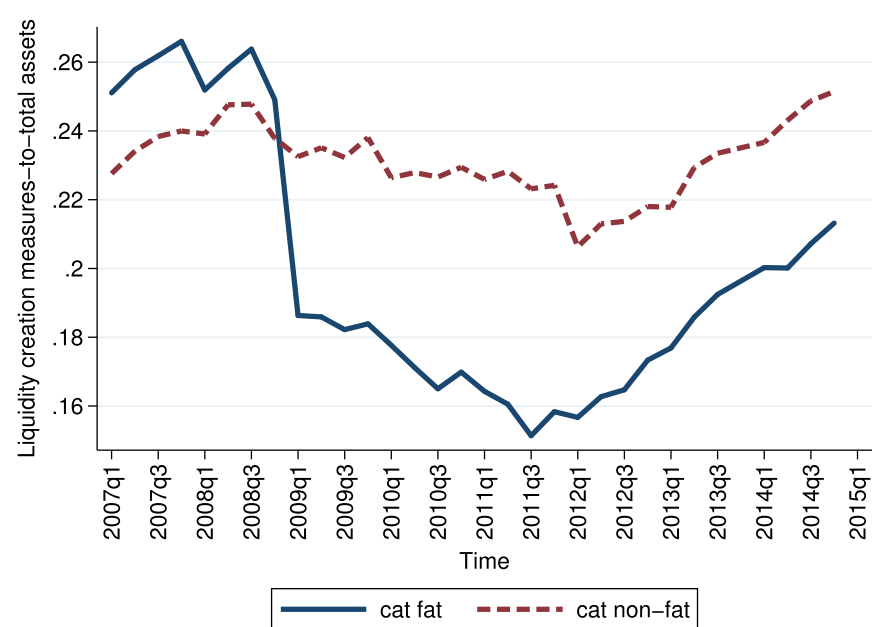

Fig. 9. Liquidity measures: cat fat and cat nonfat. The figure shows the evolution of the average Berger and Bouwman (2009) cat fat (solid line) and cat nonfat (dashed line) liquidity measures. Both indices are scaled by total assets.

a bank can sell an asset, whereas funding liquidity reflects how quickly a bank can settle its obligations. Unlike the Berger and Bouwman (2009) measure, the weights of the various components in the LMI are time-varying and reflect the maturity mismatch between assets and liabilities. We follow Bai et al. (2018) and use their data on repo market haircuts and spreads (price-based measures) to construct the index. The measure is constructed to cap- 
Table 8

Liquidity weights.

\begin{tabular}{|c|c|c|c|c|}
\hline Category & Sub- category & $\begin{array}{l}\text { Weights } \\
\text { in CATFAT }\end{array}$ & $\begin{array}{l}\text { Weights in } \\
\text { LMI (mean) }\end{array}$ & $\begin{array}{l}\text { Revised LMI } \\
\text { weights (mean) }\end{array}$ \\
\hline \multicolumn{5}{|l|}{ Panel A: Asset-side weights } \\
\hline \multirow[t]{3}{*}{ Cash } & $\begin{array}{l}\text { Cash and balances due from depository } \\
\text { institutions (Liquid) }\end{array}$ & $-1 / 2$ & 1 & -1 \\
\hline & Federal funds sold (Liquid) & $-1 / 2$ & 1 & -1 \\
\hline & $\begin{array}{l}\text { Securities purchased under agreement to resell } \\
\text { (Liquid) }\end{array}$ & $-1 / 2$ & 1 & -1 \\
\hline Trading Assets/ & Treasury securities (Liquid) & $-1 / 2$ & 0.9661693 & -0.9661693 \\
\hline Available for sale & Agency securities (Liquid) & $-1 / 2$ & 0.9671359 & -0.9671359 \\
\hline \multirow[t]{4}{*}{ / Held to maturity } & $\begin{array}{l}\text { Securities issued by state and U.S. Pol. } \\
\text { Subdivisions (Liquid) }\end{array}$ & $-1 / 2$ & 0.8312621 & -0.8312621 \\
\hline & Non-agency MBS (Liquid) & $-1 / 2$ & 0.8672858 & -0.8672858 \\
\hline & Structural product (Liquid) & $-1 / 2$ & 0.8672858 & -0.8672858 \\
\hline & Corporate debt (Liquid) & $-1 / 2$ & 0.8290137 & -0.8290137 \\
\hline Available for sale & Equity securities (Liquid) & $-1 / 2$ & 0.7790855 & -0.7790855 \\
\hline \multirow{10}{*}{ Loans } & Loans secured by real estate & & 0.7198426 & 0.7198426 \\
\hline & Residential real estate loans (semi-liquid) & 0 & & \\
\hline & Commercial real estate loans (illiquid Assets) & $1 / 2$ & & \\
\hline & Loans to finance agriculture (illiquid Assets) & $1 / 2$ & & \\
\hline & $\begin{array}{l}\text { Commercial and industrial loans (illiquid } \\
\text { Assets) }\end{array}$ & $1 / 2$ & 1 & 1 \\
\hline & Other loans (illiquid Assets) & $1 / 2$ & 0.7198426 & 0.7198426 \\
\hline & Lease financing receivables (illiquid Assets) & $1 / 2$ & 0.7198426 & 0.7198426 \\
\hline & Consumer loans (semi-liquid) & 0 & & \\
\hline & Loans to depository institutions (semi-liquid) & 0 & & \\
\hline & Loans to foreign government (semi-liquid) & 0 & & \\
\hline \multirow[t]{3}{*}{ Fixed Assets } & Premises and fixed assets (illiquid Assets) & $1 / 2$ & 0 & 1 \\
\hline & Other real estate owned (illiquid Assets) & $1 / 2$ & 0 & 1 \\
\hline & $\begin{array}{l}\text { Investment in unconsolidated subsidiaries } \\
\text { (illiquid Assets) }\end{array}$ & $1 / 2$ & 0 & 1 \\
\hline Intangible Assets & $\begin{array}{l}\text { Goodwill and other intangible assets (illiquid } \\
\text { Assets) }\end{array}$ & $1 / 2$ & 0 & 1 \\
\hline Other Assets & (illiquid Assets) & $1 / 2$ & 0 & 1 \\
\hline \multicolumn{5}{|l|}{ Panel B: Liability-side weights } \\
\hline \multirow[t]{2}{*}{ Fed funds repo } & Overnight federal funds purchased (Liquid) & $1 / 2$ & -1 & 1 \\
\hline & Securities sold under repo (Liquid) & $1 / 2$ & -1 & 1 \\
\hline \multirow[t]{4}{*}{ Deposits } & Deposits (Liquid) & $1 / 2$ & -1.087827 & 1.087827 \\
\hline & Demand/ transaction deposits (Liquid) & $1 / 2$ & & \\
\hline & Savings deposits (Liquid) & $1 / 2$ & & \\
\hline & Time deposits (semi-liquid) & 0 & & \\
\hline Trading liabilities & Trading liabilities (Liquid) & $1 / 2$ & -.9712813 & 0.9712813 \\
\hline \multirow[t]{3}{*}{ Other borrowed money } & Commercial paper (semi-liquid) & 0 & -1.006757 & 1.006757 \\
\hline & With maturity $<=1$ year (semi-liquid) & 0 & -1.087827 & 1.087827 \\
\hline & With maturity $>1$ year (semi-liquid) & 0 & -1.674883 & 1.674883 \\
\hline \multirow[t]{2}{*}{ Other Liabilities } & Subordinated notes and debentures (Illiquid) & $-1 / 2$ & -4.004571 & -4.004571 \\
\hline & Other liabilities (Illiquid) & $-1 / 2$ & -2.285964 & -2.285964 \\
\hline Total Equity Capital & Equity (Illiquid) & $-1 / 2$ & -0.1565224 & -.1565224 \\
\hline \multicolumn{5}{|l|}{ Panel C: Off balance sheet-side weights } \\
\hline \multirow[t]{3}{*}{ Contingent Liabilities- illiquid guarantees } & Unused commitments (Illiquid) & $1 / 2$ & -1.674883 & 1.674883 \\
\hline & Credit lines (Illiquid) & $1 / 2$ & -4.004571 & 4.004571 \\
\hline & All other off- balance sheet liabilities & $1 / 2$ & & \\
\hline \multirow[t]{2}{*}{ Semi-liquid guarantees } & Net credit derivatives (semi-liquid) & 0 & & \\
\hline & Net securities lent (semi-liquid) & 0 & -1.674883 & 1.674883 \\
\hline Liquid guarantees & Net participation acquired (Liquid) & $-1 / 2$ & & \\
\hline
\end{tabular}

Notes: 1. All securities regardless of maturity are taken as liquid assets under Berger-Bouwman index 2. Loans secured by real estate is a sum of residential and commercial real estate loans 3 . Unused commitments include revolving, open-end loans, unused credit card lines, to fund commercial real-estate related loans, to provide liquidity to $\mathrm{ABCP}$ conduit structures, to provide liquidity to securitization structures, other unused commitments 4 . Credit lines include financial standby letters of credit, performance standby letters of credit, commercial and similar letters of credit. 5. Haircut is the difference between asset's collateral value and its sale price. 6. Overnight index swaps (OIS) enable financial institutions to exchange fixed rate interest payments for floating rate payments based on specified principal amount.

ture a maturity mismatch, i.e., how much cash the bank can raise against its balance sheet to withstand the cash withdrawals in case of a stress event in which all claimants seek to extract the maximum liquidity. Since our goal is to employ an index of liquidity creation and not mismatch, we change the signs of the weights accordingly. A description of the weights and construction of the index is presented in Appendix B.
The estimation of Eq. (1) using this alternative measure of liquidity creation is presented in Table 7 for the three definitions of the treatment variable. Overall, it shows consistent results, with a significantly higher liquidity creation among treated banks during QE3. 


\subsection{Other robustness checks}

We perform a series of further robustness checks of our main results. First, we introduce a new treatment variable based on the mean values of MBS holdings to total assets. This dummy variable takes the value of 1 if a bank is in the top $50 \%$ of the distribution of MBS-to-total assets in 2007Q4 and 0 if it lies in the bottom $50^{\text {th }}$ percentile. Second, we conduct a sub-sample analysis by dropping observations in the first and third quarter in each year, in which small BHCs that only file the FR Y-9SP do not report data. The results are presented in Appendix C Fig. 11 and are qualitatively similar to the ones obtained in our main specification. We still find a stronger support for a differential increase in liquidity creation during QE3.

Next, in Appendix C Table 10, we consider alternative proxies for liquidity creation, namely the liquidity transformation gap proposed by Deep and Schaefer (2004) and the cat nonfat measure in Berger and Bouwman (2009). First, we construct the measure of liquidity transformation in Deep and Schaefer (2004) as the difference between liquid liabilities and liquid assets, normalized by total assets. A higher liquidity transformation gap occurs when banks are largely financed by liquid deposits and hold mostly illiquid loans. Results in Appendix Table 10 columns (1)-(6) are largely consistent with the Berger and Bouwman (2009) and Bai et al. (2018) measures of liquidity creation. Second, we construct the Berger and Bouwman (2009) cat-nonfat index (scaled by total assets) that includes loans based on category (cat) and excludes off-balance sheet items (nonfat). Fig. 9 shows that both measures of liquidity creation follow similar trends at the aggregate level: there is a spike just prior to the start of the 2008 Global financial crisis, followed by a sharp decline at the start of the crisis and a gradual increase afterwards. The increase is more pronounced after 2012, which corresponds to the start of QE3, particularly for the cat fat measure, which is the main one employed in our analysis. This suggests that the "liquidity destruction" that took place after the global financial crisis happened off-balance sheet (through, for example, loan commitments). As such, the results pertaining to the cat nonfat measure of liquidity creation are stronger across all rounds of $\mathrm{QE}$, confirming the importance of looking at off-balance sheet activity that is captured in our main specification (see Appendix Table 10, columns (7)-(12)).

\section{Conclusions}

We study the effects of large scale asset purchases on bank liquidity creation. While existing evidence shows how LSAPs can affect bank lending, our work takes a new approach by looking at whether banks that benefited more from the Fed's three rounds of QE have also contributed more to the creation of liquidity in the economy.

We show that banks with a higher share of assets in mortgagebacked securities prior to the start of the program have increased both real estate and commercial loans disproportionally more following the first and third round of QE. However, not all types of loans contribute the same to liquidity creation, which increases more when banks give out more illiquid loans such as commercial lending. As such, we find evidence that treated banks contributed more to liquidity creation only in the last round of $\mathrm{QE}$, which started in 2012, and when the Fed bought large amounts of mortgage backed securities. This points to important asymmetric effects of this unconventional monetary policy across banks and suggests that its impact on liquidity creation, one of the main functions of the banking sector, was not strong across the entire duration of the program.

In line with previous research, our results suggest that future policy interventions should consider the potential asymmetric ef- fects of asset purchase programs. In particular, evidence thus far suggests that the type of assets purchased by central banks can affect the channels through which the policy impacts the real economy. Further research can exploit whether the heterogeneity of asset types purchased through $\mathrm{QE}$ can explain, for example, the weaker evidence of a bank lending channel in European countries (Butt et al., 2014; Ryan and Whelan, 2019).

\section{Appendix A. Variables employed: construction and corresponding definition in the Fed database}

\begin{tabular}{|c|c|c|}
\hline Variable Name & Definition & Data Sources \\
\hline Securities holdings & $\begin{array}{l}\text { Held-to-maturity securities } \\
\text { (BHCK1754) + available-for-sale } \\
\text { securities (BHCK1773) }\end{array}$ & FR-Y9C \\
\hline Treasury Securities & $\begin{array}{l}\text { Trading Assets: Treasury Securities } \\
\text { (BHCK3531) }\end{array}$ & FR-Y9C \\
\hline Bank Size & Log of total assets (BHCK2170) & FR-Y9C \\
\hline Equity ratio & $\begin{array}{l}\text { Total equity capital (BHCK3210) } \\
\text { divided by total assets (BHCK2170) }\end{array}$ & FR-Y9C \\
\hline Deposits & $\begin{array}{l}\text { Non-interest bearing deposits in } \\
\text { domestic offices (BHDM6631) }+ \\
\text { interest-bearing deposits in } \\
\text { domestic offices (BHDM6636) }+ \\
\text { non-interest bearing deposits in } \\
\text { foreign offices (BHFN6631) }\end{array}$ & FR-Y9C \\
\hline Reserves & $\begin{array}{l}\text { Cash and balances due from } \\
\text { depository institutions: non } \\
\text { interest bearing balances and } \\
\text { currency } \\
\text { and coin (BHCK0081) + interest } \\
\text { bearing balances in U.S. offices } \\
\text { (BHCK0395) + interest bearing } \\
\text { balances in foreign offices, Edge } \\
\text { and Agreement subsidiaries, and } \\
\text { IBFs (BHCK0397) }\end{array}$ & FR-Y9C \\
\hline Real estate lending & $\begin{array}{l}\text { Loans secured by real estate } \\
\text { lending (BHCK1410) divided by } \\
\text { total assets (BHCK2170) }\end{array}$ & FR-Y9C \\
\hline C\&I lending & $\begin{array}{l}\text { Commercial and industrial loans to } \\
\text { U.S. addressees (BHCK1763) }+ \\
\text { commercial and industrial } \\
\text { loans to non-U.S. addressees } \\
\text { (BHCK1764) divided by total assets } \\
\text { (BHCK2170) }\end{array}$ & FR-Y9C \\
\hline Total lending & $\begin{array}{l}\text { Total loans (BHCK2122) divided by } \\
\text { total assets (BHCK2170) }\end{array}$ & FR-Y9C \\
\hline Net Income & $\begin{array}{l}\text { Net income (BHCK4340) divided by } \\
\text { total assets (BHCK2170) }\end{array}$ & FR-Y9C \\
\hline Treasury Purchases & $\begin{array}{l}\text { Amount of Treasury securities } \\
\text { purchased by the Federal Reserve } \\
\text { in a given quarter }\end{array}$ & New York Fed \\
\hline MBS Purchases & $\begin{array}{l}\text { Amount of MBS purchased by the } \\
\text { Federal Reserve in a given quarter }\end{array}$ & New York Fed \\
\hline
\end{tabular}

\section{Appendix B. Liquidity Creation Measures}

Table 8 presents the weights employed in the construction of the Berger and Bouwman (2009) and Bai et al. (2018) (LMI) measures of liquidity creation. Both measures take into account the components of on and off-balance sheet items including assets, liabilities, equity and off-balance sheet items such as loan commitments and derivatives. In Berger and Bouwman (2009), assets and liabilities are classified as liquid, semi-liquid and illiquid. LMI assigns weights to the market liquidity of assets, which range from 0 (hard or time-consuming to sell, such as fixed assets) to 1 (very liquid items such as cash). These weights are multiplied by one minus the repo haircut of the asset class (available from the authors). The calculation of asset side weights includes haircuts as it 
Table 9

The impact of $\mathrm{QE}$ on bank lending: additional controls.

\begin{tabular}{|c|c|c|c|c|c|c|}
\hline & \multicolumn{2}{|c|}{ Total Lending } & \multicolumn{2}{|c|}{ Real Estate Loans } & \multicolumn{2}{|c|}{ C\&I Loans } \\
\hline & (1) & $(2)$ & (3) & (4) & (5) & (6) \\
\hline$Q E 1 \times$ Treat $_{i}$ & $\begin{array}{l}0.010 \\
(0.008)\end{array}$ & & $\begin{array}{l}0.043^{* *} \\
(0.019)\end{array}$ & & $\begin{array}{l}-0.038 \\
(0.060)\end{array}$ & \\
\hline QE2 $\times$ Treat $_{i}$ & $\begin{array}{l}-0.001 \\
(0.014)\end{array}$ & & $\begin{array}{l}0.025^{* *} \\
(0.011)\end{array}$ & & $\begin{array}{l}0.029 \\
(0.034)\end{array}$ & \\
\hline QE3 $\times$ Treat $_{i}$ & $\begin{array}{l}0.062 * * * \\
(0.017)\end{array}$ & & $\begin{array}{l}0.062 * * * \\
(0.020)\end{array}$ & & $\begin{array}{l}0.091^{*} \\
(0.049)\end{array}$ & \\
\hline$Q E 1 \times\left(\frac{M B S}{\text { Assets }}\right)_{i}$ & & $\begin{array}{l}0.039 \\
(0.058)\end{array}$ & & $\begin{array}{l}0.154 \\
(0.160)\end{array}$ & & $\begin{array}{l}-0.025 \\
(0.331)\end{array}$ \\
\hline QE2 $\times\left(\frac{M B S}{\text { Assets }}\right)_{i}$ & & $\begin{array}{l}0.079 \\
(0.095)\end{array}$ & & $\begin{array}{l}0.197^{* *} \\
(0.092)\end{array}$ & & $\begin{array}{l}0.485^{* *} \\
(0.206)\end{array}$ \\
\hline$Q E 3 \times\left(\frac{M B S}{\text { Assets }}\right)_{i}$ & & $\begin{array}{l}0.412^{* * *} \\
(0.119)\end{array}$ & & $\begin{array}{l}0.382^{* * *} \\
(0.119)\end{array}$ & & $\begin{array}{l}0.449 \\
(0.295)\end{array}$ \\
\hline Observations & 14,611 & 29,172 & 14,565 & 29,125 & 14,588 & 29,117 \\
\hline R-squared & 0.733 & 0.771 & 0.466 & 0.566 & 0.216 & 0.311 \\
\hline Bank-level controls & Yes & Yes & Yes & Yes & Yes & Yes \\
\hline $\mathrm{QE}_{\tau} \times$ Controls & Yes & Yes & Yes & Yes & Yes & Yes \\
\hline Year-quarter fixed effects & Yes & Yes & Yes & Yes & Yes & Yes \\
\hline Bank fixed effects & Yes & Yes & Yes & Yes & Yes & Yes \\
\hline
\end{tabular}

The dependent variable in Columns (1)-(2) is log of Total lending, in Columns (3)-(4) is the log of real estate loans and in Column (5)-(6) is the log of commercial and industrial loans. Treat ${ }_{i}$ is a dummy that takes the value one for banks in the $75^{\text {th }}$ percentile of the MBS-to-total assets ratio, and zero for banks in the $25^{\text {th }}$ percentile. $\left(\frac{M B S}{A s s e t s}\right)$, is the ratio of MBS to Total assets in $2007 Q 4$. $Q E_{\tau} \in[Q E 1, Q E 2, Q E 3]$ are dummies for each $\mathrm{QE}$ wave. Bank-level controls include the log of total assets, Tier 1 capital ratio, the net income to total assets and equity over assets. Constant terms included but not reported. Robust standard errors in parentheses. ${ }^{* * *},{ }^{* *},{ }^{*}$ represent significance at the $1 \%, 5 \%$ and $10 \%$, respectively.

measures how much cash can be borrowed against the asset. Then, haircut adjusted weights are multiplied by each asset category. The liability-side weights are assigned based on maturity. Each initial weight for liabilities is multiplied by a liquidity premium (spread between the overnight index swapped rate and Treasury bill rate). Since LMI is an indicator that measures mismatch of liquidity between assets and liabilities, we revise its weights to convert it into a liquidity creation measure by changing the sign to match that of the Berger and Bouwman (2009) index (see Column 5 in Table 8).

\section{Appendix C. Robustness tests}

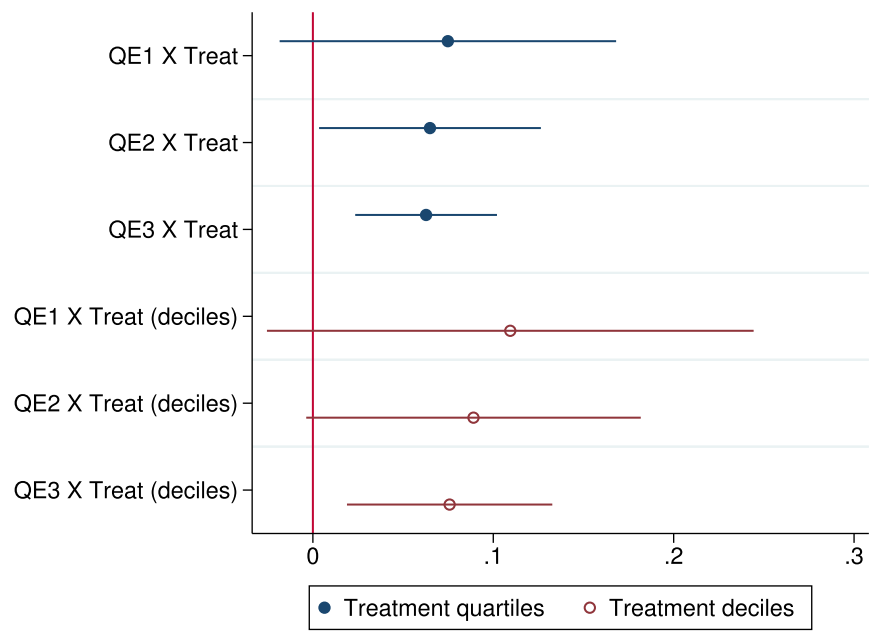

Fig. 10. Robustness Table 5 using matching techniques. The figure shows coefficient estimates of $\hat{\theta}^{\prime}$ in Eq. (1) where the dependent variable is liquidity creation to total assets. Data is weighted using propensity scores based on total assets.

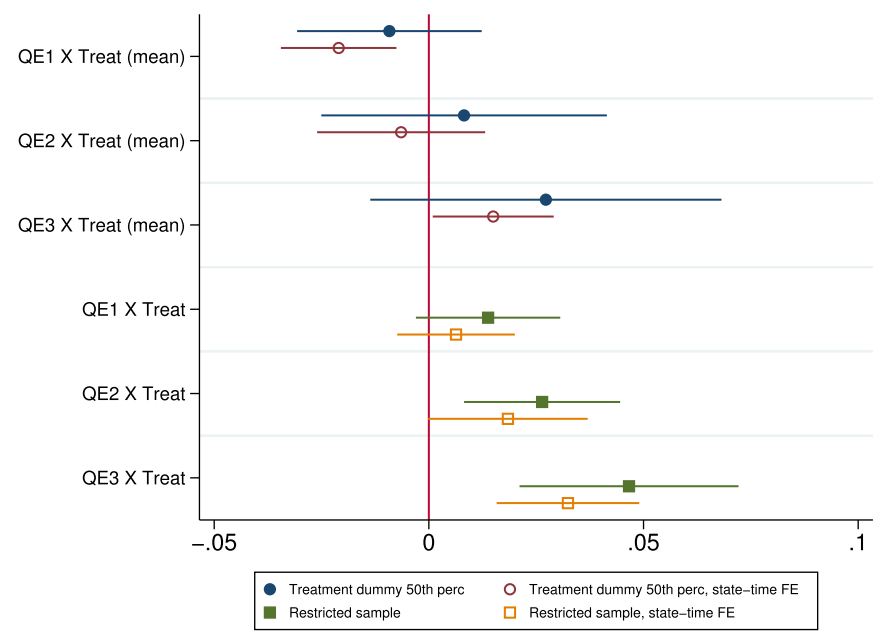

Fig. 11. Robustness test: alternative treatment definition and restricted sample analysis. The figure shows coefficient estimates of $\hat{\theta}^{\prime}$ in Eq. (1), where dependent variable is liquidity creation to total assets. The first three coefficients are from a regression that uses an alternative treatment definition as a dummy equal 1 if banks have an above the mean ratio of MBS to total assets in 2007Q4 and 0 below the mean. The last three coefficients are from a restricted sample analysis using only data on banks that report in all periods. First estimation includes year-quarter fixed effects, while the second state-time. 
Table 10

Alternative measures of liquidity creation.

\begin{tabular}{|c|c|c|c|c|c|c|c|c|c|c|c|c|}
\hline & \multicolumn{6}{|c|}{ Liquidity Transformation Gap } & \multicolumn{6}{|c|}{ cat non-fat to TA } \\
\hline & (1) & $(2)$ & (3) & (4) & (5) & (6) & (7) & (8) & (9) & $(10)$ & (11) & $(12)$ \\
\hline$Q E 1 \times$ Treat $_{i}$ & $\begin{array}{l}-0.000 \\
(0.004)\end{array}$ & $\begin{array}{l}-0.006^{*} \\
(0.004)\end{array}$ & & & & & $\begin{array}{l}0.010^{*} \\
(0.005)\end{array}$ & $\begin{array}{l}0.001 \\
(0.004)\end{array}$ & & & & \\
\hline QE2 $\times$ Treat $_{i}$ & $\begin{array}{l}0.013^{* *} \\
(0.006)\end{array}$ & $\begin{array}{l}0.005 \\
(0.005)\end{array}$ & & & & & $\begin{array}{l}0.029^{* * *} \\
(0.008)\end{array}$ & $\begin{array}{l}0.015^{* * *} \\
(0.006)\end{array}$ & & & & \\
\hline QE3 $\times$ Treat $_{i}$ & $\begin{array}{l}0.036^{* * *} \\
(0.009)\end{array}$ & $\begin{array}{l}0.029 * * * \\
(0.004)\end{array}$ & & & & & $\begin{array}{l}0.057^{* * *} \\
(0.011)\end{array}$ & $\begin{array}{l}0.046^{* * *} \\
(0.004)\end{array}$ & & & & \\
\hline$Q E 1 \times\left(\frac{M B S}{\text { Assets }}\right)_{i}$ & & & $\begin{array}{l}-0.005 \\
(0.022)\end{array}$ & $\begin{array}{l}-0.035^{* *} \\
(0.014)\end{array}$ & & & & & $\begin{array}{l}0.051^{*} \\
(0.028)\end{array}$ & $\begin{array}{l}-0.003 \\
(0.017)\end{array}$ & & \\
\hline$Q E 2 \times\left(\frac{M B S}{\text { Assets }}\right)_{i}$ & & & $\begin{array}{l}0.075^{* *} \\
(0.032)\end{array}$ & $\begin{array}{l}0.052^{* *} \\
(0.020)\end{array}$ & & & & & $\begin{array}{l}0.149 * * * \\
(0.038)\end{array}$ & $\begin{array}{l}0.106^{* * *} \\
(0.024)\end{array}$ & & \\
\hline$Q E 3 \times\left(\frac{M B S}{\text { Assets }}\right)_{i}$ & & & $\begin{array}{l}0.198^{* * *} \\
(0.048)\end{array}$ & $\begin{array}{l}0.183^{* * *} \\
(0.014)\end{array}$ & & & & & $\begin{array}{l}0.314^{* * *} \\
(0.062)\end{array}$ & $\begin{array}{l}0.290 * * * \\
(0.017)\end{array}$ & & \\
\hline$Q E 1 \times$ Treat $_{i}^{D}$ & & & & & $\begin{array}{l}0.004 \\
(0.007)\end{array}$ & $\begin{array}{l}-0.003 \\
(0.008)\end{array}$ & & & & & $\begin{array}{l}0.013 \\
(0.009)\end{array}$ & $\begin{array}{l}-0.004 \\
(0.008)\end{array}$ \\
\hline$Q E 2 \times$ Treat $_{i}^{D}$ & & & & & $\begin{array}{l}0.023^{* *} \\
(0.011)\end{array}$ & $\begin{array}{l}0.017 \\
(0.012)\end{array}$ & & & & & $\begin{array}{l}0.039^{* * *} \\
(0.013)\end{array}$ & $\begin{array}{l}0.024^{* *} \\
(0.011)\end{array}$ \\
\hline$Q E 3 \times$ Treat $_{i}^{D}$ & & & & & $\begin{array}{l}0.044^{* * *} \\
(0.014)\end{array}$ & $\begin{array}{l}0.034^{* * *} \\
(0.009)\end{array}$ & & & & & $\begin{array}{l}0.062^{* * *} \\
(0.018)\end{array}$ & $\begin{array}{l}0.046^{* * * *} \\
(0.008)\end{array}$ \\
\hline Observations & 14,620 & 14,460 & 29,181 & 29,077 & 5872 & 5488 & 14,620 & 14,460 & 29,181 & 29,077 & 5872 & 5488 \\
\hline R-squared & 0.310 & 0.878 & 0.359 & 0.869 & 0.298 & 0.903 & 0.142 & 0.865 & 0.129 & 0.840 & 0.190 & 0.898 \\
\hline Controls & Yes & Yes & Yes & Yes & Yes & Yes & Yes & Yes & Yes & Yes & Yes & Yes \\
\hline Year-Quarter Fixed Effects & Yes & & Yes & & Yes & & Yes & & Yes & & Yes & \\
\hline Bank Fixed Effects & Yes & Yes & Yes & Yes & Yes & Yes & Yes & Yes & Yes & Yes & Yes & Yes \\
\hline State-time Fixed Effects & & Yes & & Yes & & Yes & & Yes & & Yes & & Yes \\
\hline Controls & Yes & Yes & Yes & Yes & Yes & Yes & Yes & Yes & Yes & Yes & Yes & Yes \\
\hline Bank Fixed Effects & Yes & Yes & Yes & Yes & Yes & Yes & Yes & Yes & Yes & Yes & Yes & Yes \\
\hline Year-Quarter Fixed Effects & Yes & & Yes & & Yes & & Yes & & Yes & & Yes & \\
\hline State-time Fixed Effects & & Yes & & Yes & & Yes & & Yes & & Yes & & Yes \\
\hline
\end{tabular}

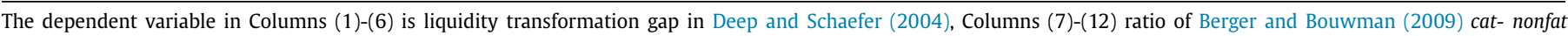

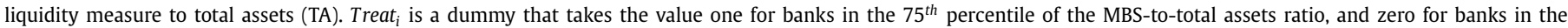

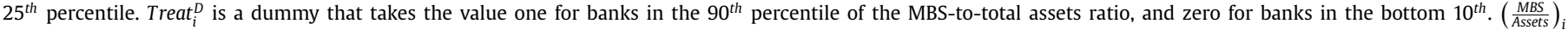

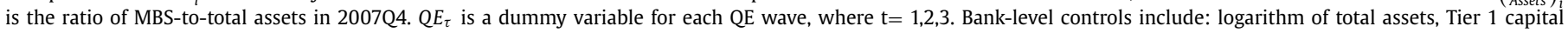

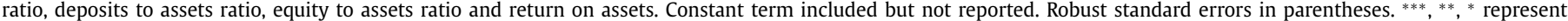
significance at the $1 \%, 5 \%$ and $10 \%$, respectively.

\section{CRediT authorship contribution statement}

Supriya Kapoor: Conceptualization, Data curation, Methodology, Software, Visualization, Writing - original draft, Writing review \& editing. Oana Peia: Conceptualization, Data curation, Methodology, Software, Visualization, Writing - original draft, Writing - review \& editing.

\section{References}

Acharya, V.V., Mora, N., 2015. A crisis of banks as liquidity providers. Journal of Finance 70 (1), 1-43.

Bai, J., Krishnamurthy, A., Weymuller, C.-H., 2018. Measuring liquidity mismatch in the banking sector. J Finance 73 (1), 51-93.

Bauer, M.D., Rudebusch, G.D., 2014. The signaling channel for federal reserve bond purchases. International Journal of Central Banking 10 (3), 233-289.

Berger, A.N., Bouwman, C.H., 2009. Bank liquidity creation. Review of Financial Studies 22 (9), 3779-3837.

Berger, A.N., Bouwman, C.H., 2013. How does capital affect bank performance during financial crises? J Financ Econ 109 (1), 146-176.

Berger, A.N., Bouwman, C.H., 2017. Bank liquidity creation, monetary policy, and financial crises. Journal of Financial Stability 30, 139-155.

Berger, A.N., Bouwman, C.H., Kick, T., Schaeck, K., 2016. Bank liquidity creation following regulatory interventions and capital support. Journal of Financial Intermediation 26, 115-141.

Berger, A.N., Sedunov, J., 2017. Bank liquidity creation and real economic output. Journal of Banking \& Finance 81, 1-19.

Bianchi, J., Bigio, S., 2014. Banks, liquidity management and monetary policy. Technical Report. National Bureau of Economic Research.

Boyd, J.H., Prescott, E.C., 1986. Financial intermediary-coalitions. J Econ Theory 38 (2), 211-232

Brunnermeier, M.K., Sannikov, Y., 2016. The I theory of money. Technical Report. National Bureau of Economic Research.

Bryant, J., 1980. A model of reserves, bank runs, and deposit insurance. Journal of Banking \& Finance 4 (4), 335-344.

Butt, N., Churm, R., McMahon, M. F., Morotz, A., Schanz, J. F., 2014. QE and the bank lending channel in the united kingdom.
Chakraborty, I., Goldstein, I., MacKinlay, A., 2020. Monetary stimulus and bank lending. J Financ Econ 136 (1), 189-218.

Cornett, M.M., McNutt, J.J., Strahan, P.E., Tehranian, H., 2011. Liquidity risk management and credit supply in the financial crisis. J Financ Econ 101 (2), 297-312.

Dagher, J., Kazimov, K., 2015. Bank liability structure and mortgage lending during the financial crisis. J Financ Econ 116 (3), 565-582.

D'Amico, S., English, W., López-Salido, D., Nelson, E., 2012. The federal reserve's large-scale asset purchase programmes: rationale and effects. The Economic Journal 122 (564), F415-F446.

D'Amico, S., King, T.B., 2013. Flow and stock effects of large-scale treasury purchases: evidence on the importance of local supply. J Financ Econ 108 (2), 425-448.

Deep, A., Schaefer, G., 2004. Are Banks Liquidity Transformers? Working Paper Series rwp04-022. Harvard University, John F. Kennedy School of Government.

Di Maggio, M., Kermani, A., Palmer, C.J., 2020. How quantitative easing works: evidence on the refinancing channel. Rev Econ Stud 87 (3), 1498-1528.

Diamond, D.W., 1984. Financial intermediation and delegated monitoring. Review of Economic Studies 51 (3), 393-414.

Díaz, V., Huang, Y., 2017. The role of governance on bank liquidity creation. Journal of Banking \& Finance 77, 137-156.

Donaldson, J.R., Piacentino, G., Thakor, A., 2018. Warehouse banking. J Financ Econ 129 (2), 250-267.

Gagnon, J., Raskin, M., Remache, J., Sack, B., 2011. The financial market effects of the Federal Reserve's large-scale asset purchases. International Journal of Central Banking 7 (1), 3-43.

Gorton, G., Pennacchi, G., 1990. Financial intermediaries and liquidity creation. Journal of Finance 45 (1), 49-71.

Gorton, G., Winton, A., 2003. Financial intermediation. In: Handbook of the Economics of Finance, 1. Elsevier, pp. 431-552.

Holmstrom, B., Tirole, J., 1997. Financial intermediation, loanable funds, and the real sector. Q J Econ 112 (3), 663-691.

Horváth, R., Seidler, J., Weill, L., 2014. Bank capital and liquidity creation: grangercausality evidence. Journal of Financial Services Research 45 (3), 341-361.

Huang, S.-C., Chen, W.-D., Chen, Y., 2018. Bank liquidity creation and CEO optimism. Journal of Financial Intermediation 36, 101-117.

Jiang, L., Levine, R., Lin, C., 2019. Competition and bank liquidity creation. Journal of Financial and Quantitative Analysis 54 (2), 513-538.

Joyce, M., Spaltro, M., 2014. Quantitative easing and bank lending: a panel data approach. 
Kandrac, J., Schlusche, B., 2017. Quantitative easing and bank risk taking: evidence from lending.

Kashyap, A.K., Rajan, R., Stein, J.C., 2002. Banks as liquidity providers: an explanation for the coexistence of lending and deposit-taking. J Finance 57 (1), 33-73.

Kashyap, A.K., Stein, J.C., 2000. What do a million observations on banks say about the transmission of monetary policy? American Economic Review 90 (3), 407-428.

Kim, D., Sohn, W., 2017. The effect of bank capital on lending: does liquidity matter? Journal of Banking \& Finance 77, 95-107.

Krishnamurthy, A., Vissing-Jorgensen, A., 2011. The effects of quantitative easing on interest rates: channels and implications for policy. Technical Report. National Bureau of Economic Research.

Kurtzman, R., Luck, S., Zimmermann, T., 2018. Did qe lead banks to relax their lending standards? evidence from the Federal Reserve's lsaps. Journal of Banking \& Finance 105403.
Luck, S., Zimmermann, T., 2020. Employment effects of unconventional monetary policy: evidence from QE. J Financ Econ 135 (3), 678-703.

Nichols, A., 2007. Causal inference with observational data. Stata Journal 7 (4), 507. Ramakrishnan, R.T., Thakor, A.V., 1984. Information reliability and a theory of financial intermediation. Rev Econ Stud 51 (3), 415-432.

Rodnyansky, A., Darmouni, O.M., 2017. The effects of quantitative easing on bank lending behavior. Review of Financial Studies 30 (11), 3858-3887.

Ryan, E., Whelan, K., 2019. Quantitative easing and the hot potato effect: evidence from euro area banks. UCD Centre for Economic Research Working Paper Series, No. WP19/01.

Washington Post, T., 2012. Qe3: Reactions to the fed's big stimulus move, available online: https://www.washingtonpost.com/gdpr-consent/?destination=\%2fnews\% 2fwonk\%2fwp\%2f2012\%2f09\%2f13\%2fqe3-reactions-to-the-feds-big-stimulusmove\%2f\%3f\&utm_term=.432756e93168. 